FaCUldade de EConomia, AdministraÇão, Contabilidade e CiênCia da INFORMAÇÃO E DOCUMENTAÇÃO (FACE)

Programa de Pós-Graduação em Administração - PPGa

THALITA BARROS BALDINO

VIVÊNCIAS DE PRAZER E DE SOFRIMENTO NO TRABALHO DE GESTORES DE PESSOAS

Brasília - DF

2008 


\section{VIVÊNCIAS DE PRAZER E DE SOFRIMENTO NO TRABALHO DE GESTORES DE PESSOAS}

Projeto de monografia apresentado ao Programa de Pós-Graduação em Administração da Faculdade de Economia, Administração, Contabilidade e Ciência da Informação e Documentação (FACE), da Universidade de Brasília, como requisito parcial à obtenção do grau de Especialista em Gestão de Pessoas.

Orientador: Prof. Dr. Marcus Vinícius Soares Siqueira 


\section{SUMÁRIO}

1. INTRODUÇÃ

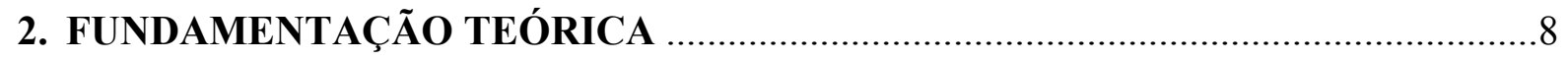

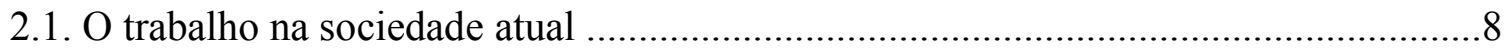

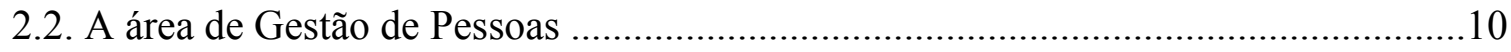

2.3.Prazer e Sofrimento no Trabalho ............................................................................ 13

2.3.1 Considerações iniciais acerca do Prazer e Sofrimento no Trabalho ....................14

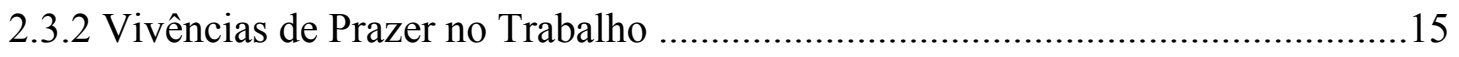

2.3.3 Vivências de Sofrimento no Trabalho ..............................................................17

2.3.4 Estratégias de mediação …...............................................................................18

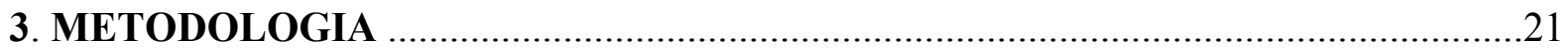

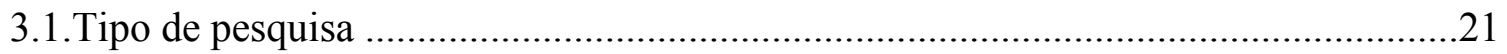

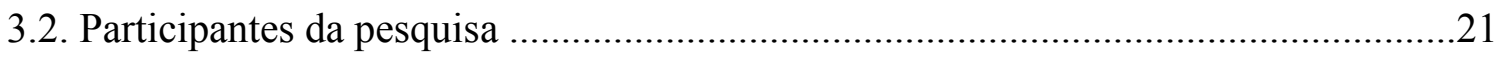

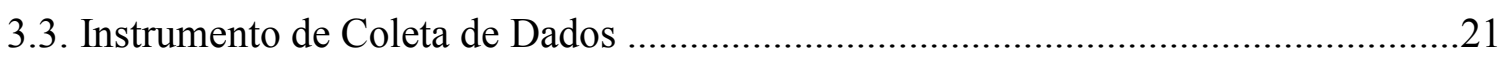

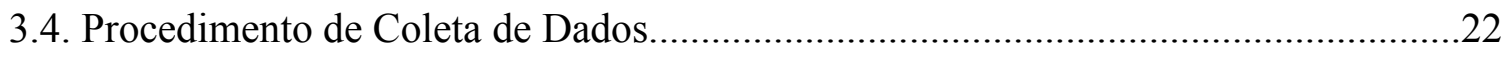

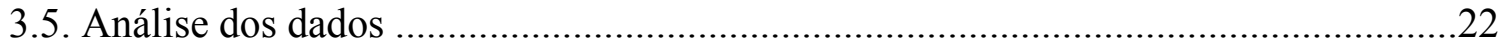

3.6. Caracterização das Empresas Pesquisadas .................................................................23

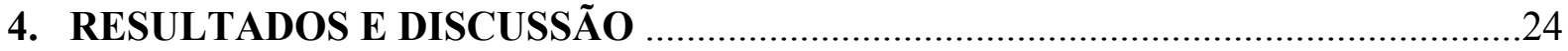

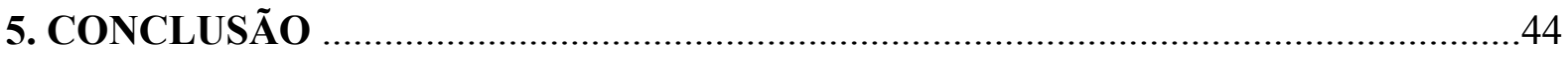

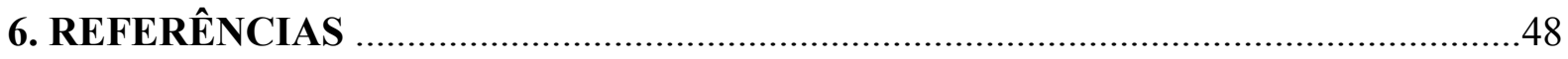

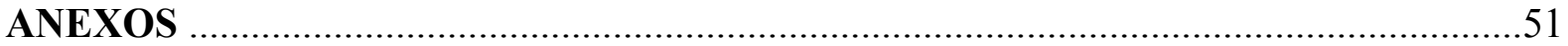




\section{AGRADECIMENTOS}

Aos meus pais, José Maria e Maria Helena, e irmãos, Thiago e Thales, pessoas especiais cujo amor, presença e apoio eu sinto e preciso em todos os momentos de minha vida.

Ao meu noivo, Leandro, pelo apoio e incentivos necessários para alcançar essa importante meta e com quem sempre poderei contar.

Ao professor Dr. Marcus Vinícius Soares Siqueira, com sua dedicação e incrível sabedoria, me ajudou a conduzir este processo, fazendo com que as minhas expectativas iniciais fossem superadas.

E finalmente, meu especial agradecimento a todos os Gestores e Assistentes que se dispuseram a participar desta pesquisa, contribuindo para o alcance dos objetivos. 


\section{Resumo}

Este estudo tem como objetivo verificar como se configuram as vivências de prazer e sofrimento no trabalho de gestores de pessoas e seus assistentes e quais estratégias de mediação são mobilizadas para o enfrentamento do sofrimento a partir do referencial teórico da Psicodinâmica do Trabalho. Foi utilizado o método qualitativo para a coleta, tratamento e análise dos dados. A pesquisa foi realizada com seis trabalhadores da área de Gestão de Pessoas, o instrumento utilizado para coleta de dados foi entrevista individual semiestruturada e para fins de análise, as entrevistas transcritas foram submetidas à análise utilizando a ANS - Análise dos Núcleos e dos Sentidos. Verificou-se que as empresas pesquisadas não têm ainda uma compreensão do real valor da área de Gestão de Pessoas, o que evidencia o apego às formas tradicionais de poder e dominação das estruturas organizacionais. As empresas têm como característica comum serem empresas familiares, diretoria centralizadora e focada nos resultados. A dinâmica que envolve o prazer e o sofrimento no trabalho foi verificada constantemente na fala dos trabalhadores. O prazer esteve vinculado ao salário e à realização profissional. Mas a predominância foi a de sofrimento causado principalmente pela descrença na empresa associado à incompatibilidade entre organização do trabalho e o investimento psicológico dos trabalhadores e inclusive, pela ausência de suporte organizacional.

Palavras-chave: sofrimento, trabalho, psicodinâmica, Gestores de Pessoas. 


\section{Introdução}

O conceito de trabalho, ao longo do tempo, foi se modificando de acordo com o contexto histórico e social. No final do século XX, com a hegemonia do pensamento econômico, ampliou-se a influência das organizações na sociedade e na vida dos indivíduos, fazendo com que estes manifestassem diferentes concepções sobre o trabalho.

Dejours (2000) relata que o trabalho pode ser ambivalente: ao mesmo tempo em que pode trazer sofrimento, alienação e adoecimento, pode também ser mediador da saúde e da realização pessoal. Isso pode gerar uma contradição guiada pelo movimento de luta do trabalhador para busca constante do prazer e evitação do sofrimento, na tentativa de manter seu equilíbrio psíquico.

As vivências de prazer-sofrimento têm sido estudadas pela psicodinâmica do trabalho, que investiga as dinâmicas de prazer e sofrimento decorrente da interação sujeito-trabalho. $\mathrm{O}$ objeto de estudo da ergonomia da atividade também é esta interação, buscando, por meio da análise desta relação, a adaptação do ambiente de trabalho ao indivíduo, para, assim, promover o bem-estar no trabalho. Deste modo, opõe-se ao modelo taylorista, que buscava a adaptação do indivíduo ao trabalho (FERREIRA, 2000).

A psicodinâmica do trabalho tem como objetivo o bem-estar e a saúde do trabalhador, de modo que se torne apto para o trabalho. A organização, as condições e as relações de trabalho são os principais antecedentes do prazer-sofrimento do trabalhador e tais vivências são o objeto de estudo da psicodinâmica do trabalho. Entretanto, o contexto de trabalho não determina o surgimento de uma ou outra vivência. As vivências de prazer-sofrimento ocorrem a partir da inter-relação entre a realidade concreta de trabalho e a subjetividade do trabalhador (FERREIRA; MENDES, 2001).

Para a realização deste estudo, a categoria profissional escolhida é a de gestores de pessoas, decisão esta sustentada no intuito de privilegiar as falas desses profissionais por acreditar que são depositários de muitas histórias ouvidas, presenciadas, silenciadas, capturadas e regradas. Esses profissionais têm exatamente, por atribuição, lidar com questões críticas para o bem-estar das pessoas na Organização.

É importante ressaltar que a área de Gestão de Pessoas é demasiadamente vasta, composta de múltiplas temáticas, constituindo uma fonte inesgotável de questionamentos e abordagens. Não temos a pretensão, aqui, de explorá-la em todas as suas facetas, mas apenas naquelas que consideramos relevantes para os objetivos desta pesquisa. Certamente, estaremos passando ao largo de outras questões de suma importância, mas que não estão no 
foco deste trabalho.

A compreensão que os gestores de pessoas possuem a respeito do sofrimento humano nas organizações influi nas concepções, atitudes e decisões por eles tomadas e na maneira como lidam com as pessoas na Organização. Por outro lado, oferece o suporte ideológico às estratégias e às ações da área de Gestão de Pessoas. E se, por alguma razão, ai ocorre uma dissonância, surge o conflito de valores e o sofrimento.

Pode-se imaginar que o profissional de Gestão de Pessoas de uma organização construa representações muito peculiares sobre o tema, seja com base em suas próprias vivências de prazer e sofrimento - oriundas do embate entre os registros subjetivos de cada um e as características da organização do trabalho na unidade de Gestão de Pessoas - seja com base na percepção e no entendimento que constroem sobre o que se passa com seus companheiros de empresa.

Desta forma, a simples existência de prazer ou sofrimento não é um indicativo de saúde, e sim a diversidade de estratégias utilizadas pelo trabalhador na tentativa de transformar situações geradoras de sofrimento em geradoras de prazer. Tais estratégias caracterizam uma dinâmica particular às vivências de prazer e sofrimento (FERREIRA; MENDES, 2003).

A partir do exposto, percebe-se a necessidade de investigar a fundo como se configuram a dinâmica prazer-sofrimento no trabalho de gestores de pessoas e quais estratégias de mediação são mobilizadas para o enfrentamento do sofrimento a partir do referencial teórico da Psicodinâmica do Trabalho.

A saúde mental dos trabalhadores tornou-se alvo de recorrentes pesquisas que trabalham questões específicas, tais como: "o reconhecimento, a depressão relacionada aos Dorts, a alcoolização, as defesas, entre outros" (MENDES, 2007). Frente a essa demanda, a Psicodinâmica do Trabalho vem produzindo conhecimentos acerca da subjetividade envolvida na relação entre o contexto do trabalho e o indivíduo, revelada mediante as vivências de prazer e sofrimento no trabalho e as estratégias de mediação do sofrimento.

Essa pesquisa contribuirá para refletir sobre a subjetividade dos gestores de pessoas quando confrontados pelas vivências de prazer e sofrimento no trabalho, propiciando o conhecimento sobre as vicissitudes inerentes à sua atividade.

Além disso, coloca em questão o modelo de processo de trabalho prescrito e sua influência na produção, evidenciando que a gestão coletiva da organização do trabalho permite a emergência do prazer ou a transformação do sofrimento em criatividade, na medida em que possibilita o engajamento do trabalhador na atividade sem maiores prejuízos à saúde 
mental.

A pesquisa oferece, ainda, insumos para a formação do profissional de Gestão de Pessoas e para a reflexão sobre o papel dos profissionais desta área em geral no interior das organizações, tendo como objetivo geral analisar a dinâmica de prazer-sofrimento e as estratégias de mediação do sofrimento de gestores de pessoas e, como objetivos específicos caracterizar o contexto do trabalho de gestores de pessoas a partir das dimensões: organização do trabalho, relações socioprofissionais e subjetividade e trabalho; analisar, como é possível diminuir o sofrimento no trabalho ou até mesmo transformá-lo em sofrimento criativo; definir, como é possível potencializar o prazer no trabalho, na visão desses profissionais e descrever o papel do profissional de gestão de pessoas face ao fenômeno prazer e sofrimento.

Portanto, o estudo é composto por uma fundamentação teórica, baseada na Psicodinâmica do Trabalho, a qual contextualiza o mundo do trabalho atual e o trabalho na área de Saúde. A seguir, será apresentada a fundamentação teórica, a metodologia, os resultados obtidos a partir da análise dos dados coletados por meio de entrevistas semiestruturadas individuais, a discussão, confrontando estes dados com a Psicodinâmica do Trabalho e a conclusão, através de um levantamento geral do que foi apresentado no trabalho. 


\section{Fundamentação Teórica}

Para uma ampla compreensão do trabalho de gestores de pessoas, será feito a seguir uma breve contextualização sobre o trabalho, suas principais concepções e paradigmas e apresentado o levantamento da literatura a respeito das variáveis tratadas nessa pesquisa - o trabalho de gestores de pessoas, vivências de prazer e sofrimento, estratégias de mediação no trabalho - tendo as contribuições de Dejours (2000) e outros autores no entendimento das vivências de prazer e sofrimento no trabalho.

\subsection{O trabalho na sociedade atual}

A classe trabalhadora compreende a totalidade dos assalariados, homens e mulheres que vivem da venda da sua força de trabalho - a classe-que-vive-do-trabalho, conforme nossa denominação (Antunes, 1995 e 1999) - e que são despossuídos dos meios de produção, não se restringindo aos trabalhadores manuais diretos, incorporando também a totalidade do trabalho social, a totalidade do trabalho coletivo que vende sua força de trabalho como mercadoria em troca de salário.

O mercado de trabalho tem passado por várias alterações nos últimos anos, decorrentes do processo de globalização que altera na forma como as pessoas se relacionam entre si, seus hábitos e seu modo de trabalhar. $\mathrm{O}$ aumento da integração e da interdependência dos países, premissa básica da globalização, trás como conseqüência o aumento da competitividade de mercado, resultando na necessidade de se buscar várias mudanças, tanto nas organizações quanto em seus funcionários (ABRAHÃO; ALMEIDA, 1998). A economia globalizada exige muito mais do trabalhador, exige um profissional competitivo, extremamente produtivo, criativo, que demonstre resiliência, comprometimento com a organização, autodisciplina, dentre outras competências.

Nota-se hoje o paraíso e também o inferno temporário das empresas e de todos os que nelas trabalham. A questão da temporalidade está permanentemente presente e é representativa desse contexto de mudanças aceleradas, no qual tudo se tornou descartável. Os conteúdos devem estar sempre atualizados, os indivíduos e os grupos devem buscar sempre mais, os saberes se tornam imprestáveis com uma enorme velocidade, os heróis de hoje não servem mais como referência para amanhã, os valores atuais já estão obsoletos. A excelência torna-se a palavra chave e a condição imprescindível de sobrevivência de pessoas e empresas (FREITAS, 2000). 
Nesse sentido, cabe ao indivíduo inserir-se e desenvolver-se nesse ambiente de competitividade e de atualizações constantes, o que de certa forma resulta num considerável nível de angústia, ansiedade e sofrimento. Esta competitividade, cada dia mais acelerada, pode ser explicada pela diminuição da oferta de empregos formais, exigindo assim uma maior dedicação do funcionário no seu trabalho. Desta forma, as relações interpessoais estão cada vez mais vinculadas ao trabalho, visto que o funcionário deve ser cada vez mais comprometido e dedicado a sua organização (FREITAS, 2000).

A respeito disso, Freitas (2000, p. 63) coloca que: "a carreira e o status profissional tornam-se os elementos organizadores da vida do indivíduo, aquilo que lhe dá sentido, autoimagem e reconhecimento, único referencial capaz de proporcionar-lhe sucesso e realização pessoal. A identidade profissional torna-se a identidade pessoal".

Como a vida das pessoas está construída em torno do trabalho, acabam assumindo esse papel principal na vida do ser humano, tanto que a idéia de que o trabalho enobrece o homem está cada dia mais presente em nosso consciente e inconsciente, colocando de lado ou excluindo, muitas vezes, dimensões importantes da vida do homem, como o lazer e o prazer (ENRIQUEZ, 1997).

Com relação à organização do trabalho, Enriquez (1997) a vê como um sistema que é ao mesmo tempo cultural, simbólico e imaginário. O conjunto de normas, regras, valores e mitos produzidos na vivência organizacional assumem o caráter de realidade, mesmo para as outras esferas externas à organização, ditando o comportamento e contaminando o pensamento e as suas atitudes. $\mathrm{O}$ autor afirma ainda que a empresa é uma das principais instituições sociais onde o indivíduo estrutura sua vida. A empresa torna-se para o indivíduo o lugar ideal para alcançar seus objetivos, mesmo que para isso ele tenha que descaracterizar sua identidade e perder a direção de sua própria vida. Siqueira (2006) coloca que a empresa é uma família que acolhe o indivíduo na condição de que este aceite todos os seus códigos e valores, onde a vida do indivíduo passa a pertencer cada vez mais à realidade da empresa.

Em relação a esse processo de dominação, Pagès (1987), coloca que os indivíduos participam desse processo pelo fato de participarem de alguma forma da ideologia da empresa, compartilhando-a posteriormente. Essa dominação se tornará cada vez maior, e tomará conta do inconsciente do indivíduo, tornando-se fonte de prazer e de sofrimento para ele. Segundo Siqueira (2006), o indivíduo se envolverá emocionalmente com a empresa, lutará pelo sucesso, que é o seu próprio sucesso, mesmo que isso não se materialize e permaneça apenas em termos institucionais.

Le Goff (1995 apud Freitas, 2000) analisa a estranha relação nas empresas entre 
obediência e liberdade. Ressalta a autonomia e a responsabilidade que combinam com vários instrumentos de avaliação e controle, cada vez mais comum e sofisticado, que inclui os aspectos psicológicos inconscientes. Coloca ainda o problema do emprego, que dá lugar hoje a uma verdadeira chantagem colocando o emprego como privilégio em troca do silêncio sobre as condições de trabalho e os efeitos desestabilizadores das novas práticas de gestão.

A respeito disso, pode-se considerar que o indivíduo está cada vez mais descartável para as organizações, admitindo e demitindo sem nenhuma preocupação com o que essa demissão acarretará para o empregado ou até mesmo para a sua família (SIQUEIRA, 2006). O desemprego torna-se ameaçador cada vez mais na vida do indivíduo que vive numa constante ansiedade diante da incerteza do emprego. Essa ameaça influencia em como a organização vai se relacionar com seus empregados, especialmente em termos de controle do indivíduo (SIQUEIRA, 2006, p.31).

Segundo Enriquez (1997), as organizações preferem os que tem sede pelo poder e que são mais facilmente conduzidos pela cultura da organização, do que aqueles que tem pensamentos próprios, que transgridem as regras impostas. Porém, "ao indivíduo cabe saber transgredir no momento certo e de acordo com estratégias habilidosamente definidas para que não ocorra uma ruptura definitiva com o poder estabelecido" (SIQUEIRA, 2006, p.61).

A relação que os indivíduos mantêm com a organização não é meramente objetiva, passível do cálculo claro e racional, e sim mediatizada por laços psicológicos. A organização cria estratégias que possam levá-las ao controle do indivíduo e com isso alcançar os resultados por ela pretendidos (SIQUEIRA, 2006).

\subsection{A área de Gestão de Pessoas}

A área de Gestão de Pessoas tem passado por grandes transformações nestes últimos anos, em função da necessidade das empresas de incrementar a sua capacidade competitiva para enfrentar a concorrência dos mercados globalizados. Deve-se considerar a transição do termo Administração de Recursos Humanos - ARH para Gestão de Pessoas. A sutil diferença de nomenclatura traz no seu bojo a grande amplitude que passa a ter esta área, com novas dimensões e complexidades.

O termo Administração de Recursos Humanos apresenta uma conotação mecanicista e a sua substituição por um conceito mais amplo facilita a compreensão da significância que esse construto adquiriu nos últimos anos. É importante destacar que a área de Gestão de Pessoas é muito vasta, com várias temáticas, que é composta por vários questionamentos e 
abordagens (MARTININGO, 2007). Não serão exploradas nesse trabalho essas múltiplas temáticas, e sim somente aquelas que se considerarem relevantes para os objetivos dessa pesquisa.

A gestão de pessoas é a função organizacional que trata de pessoas — os funcionários, assim como suas atividades de gestão, utilizam as pessoas para o alcance dos objetivos empresariais, reconhecendo que a qualidade dessa gestão influencia diretamente a capacidade da organização e de seus empregados em levar a cabo suas incumbências (JABBOUR; SANTOS, 2007 ).

Segundo Martiningo (2007), essa área não pode resumir-se a um conjunto de políticas e práticas, tampouco ser definida como responsabilidade de um departamento ou de uma função e, portanto, também a introdução de políticas de prevenção e de monitoramento dos casos de prazer e sofrimento no trabalho não pode restringir-se somente à área de gestão de pessoas.

É um fato que, perante as atuais transformações sócio-econômicas, as empresas têm alterado significativamente o modo como gerem as pessoas. Essas mudanças ocorrem graças à intensificação da competitividade. A agilidade da inovação e a criatividade passam a ser decisivas para a sobrevivência das empresas. Após investir na anulação das capacidades cognitivas dos trabalhadores, dificultando o desenvolvimento de cada um, o capital chega a um outro momento em que necessita de um trabalhador não apenas qualificado, mas competente, inteligente, questionador, crítico, inovador, que possa criar alternativas que mantenham a empresa competitiva (SIQUEIRA, 2006).

Nova concepção de empresa competitiva começa a surgir. Esta concepção transformada da organização prevê como políticas de gestão de pessoas a manutenção das pessoas na organização, mas de modo flexível, com intercâmbio de carreiras e funções, sendo o foco colocado no desempenho, aliado a incentivos grupais, o que favorece a atuação das equipes. Fica clara, portanto, a importância da preparação destes empregados para funções presentes e futuras, além das habilidades de se trabalhar em grupos (ALBUQUERQUE, 1992).

O papel estratégico a ser desempenhado pela área de Gestão de Pessoas é o de repensar as atividades próprias da área, ou seja, integrar os objetivos de longo prazo da organização, as variáveis relevantes do ambiente e as necessidades decorrentes em termos de pessoas (LACOMBE; TONELLI, 2001).

Conforme ressalta Albuquerque (1987), a necessidade de se pensar em recursos humanos de forma estratégica decorreu, principalmente, do reconhecimento da importância de 
se considerar o ambiente externo na formulação das estratégias de negócios e da existência de um gap entre as necessidades previstas para a implantação destas estratégias e as realidades que as organizações enfrentavam em termos de pessoas para implantá-las.

As organizações funcionam por meio das pessoas que delas fazem parte, que decidem e agem em seu nome. Elas não são mais do que um conjunto de pessoas que coordenam suas ações com o intuito de conseguir os objetivos que interessam a todos, mesmo que esse interesse possa se dever a motivos muito diferentes (PÉREZ LÓPEZ, 1996 apud NOBREGA \& FERRUCCIO, 2002).

Há muito tempo que bons gestores sabem, intuitivamente, que uma boa gestão de pessoas trás resultados positivos para a organização. Essa idéia é confirmada, segundo Nobrega e Ferruccio (2002), pelo discurso da gestão de pessoas, que tem como objetivo atrair, desenvolver e manter pessoas competentes, motivadas e comprometidas, buscando o equilíbrio entre suas expectativas e as necessidades da empresa, criando valor e contribuindo para o alcance de melhores resultados. Acrescentando que a organização fará uso de vários instrumentos para alcançar esse objetivo, especialmente da humanização das relações de trabalho (SIQUEIRA, 2006).

De acordo com Siqueira (2006), as políticas de recursos humanos deveriam visar o desenvolvimento da criatividade de seus membros, proporcionando a inovação de seus produtos e serviços e, concomitantemente o comprometimento com o alcance dos objetivos pretendidos pela organização.

Este modelo de política favorece a emancipação dos indivíduos, o seu desenvolvimento político e cognitivo e o seu acesso a uma identidade autônoma na organização. Neste modelo de gestão, reconhece-se a existência de conflitos na organização, mas busca-se superá-los através da negociação, chegando-se a propostas de consenso entre as partes. Essas políticas visam oferecer possibilidades de debate e negociação na organização, a fim de promover o contraditório em busca de soluções mais completas em torno das quais se obtenham os consensos. Busca-se vislumbrar as diversas opções de ação antes de decidir, tendo-se como pressuposto que esta é uma forma mais inteligente de se lidar com a realidade complexa (VASCONCELOS, MASCARENHAS; VASCONCELOS, 2004).

A área de Gestão de Pessoas vive permanentemente uma tensão: a contradição entre a individualização e a busca de sinergia coletiva. Segundo Freitas (2000), a revalorização do trabalho em equipe é primordial na nova dinâmica que se instaurou nas empresas, onde o que importa são os conhecimentos rápidos e superáveis, resultando na insegurança das pessoas referente a seus saberes. Se por um lado a cooperação grupal é requisito fundamental, por 
outro o individualismo é o que move o mercado atual. As pessoas, de acordo com Martiningo (2007), são constantemente estimuladas a construir o seu projeto pessoal, uma vez que a ascensão profissional transformou-se no grande parâmetro de sucesso individual. Isso pode dar lugar à prática da competição, do projeto coletivo da organização que fincam fissuras destrutivas e individualistas.

Segundo Martiningo (2007), esse contexto explica a tensão que a área de gestão de pessoas vive ao incentivar a individualização que faz com que o funcionário dedique-se ao extremo à organização e ao mesmo tempo, busque a sinergia coletiva, por meio do estímulo do trabalho em equipe. Esse é um problema muito comum nos discursos organizacionais onde se verifica a distância entre a intencionalidade e a prática. A utilização de jogos de palavras muitas vezes bonitas e sentidas pelos colaboradores, mas bastante distante das práticas reais, tem provocado muitas vezes confusões entre conceitos bastante distintos, tal como o de individualização e sinergia coletiva.

Ao mesmo tempo em que a área de gestão de pessoas fala em sinergia de grupo, ela desenvolve programas com base em metas individuais que estimula a competição entre as pessoas. Além disso, ao mesmo tempo em que a organização exige do funcionário o engajamento aos seus objetivos ela usa a estratégia do "não contrato" pela qual não se pode garantir nada ao funcionário em nome da competitividade crescente (FREITAS, 2000).

Para escapar desse círculo cabe aos gestores perceber de forma diferente a relação das pessoas com o mundo organizacional e admitir que a decisão e a operacionalização de estratégias dependem de pessoas (PIMENTA, 1999).

A gestão de pessoas poderia preocupar-se mais com a representação simbólica de seus benefícios, da grandiosidade da empresa, da entrega de vida quase absoluta que o trabalho acaba consumando (MARTININGO, 2007). Deve-se acreditar que as pessoas são essenciais ao sucesso socioeconômico das organizações e que a ação dos gestores é de fundamental importância e que eles devem renovar sua forma de atuação, enriquecendo sua compreensão sobre a complexidade das individualidades e a experiência vivida em coletivo (DAVEL; VERGARA, 2001).

\subsection{Prazer e Sofrimento no Trabalho}

O objeto de estudo da Psicodinâmica do Trabalho é o estudo das relações dinâmicas entre a organização do trabalho e os processos de subjetivação envolvidos e que se manifestam nas vivências de prazer e sofrimento, nas estratégias de mediação, nas patologias 
sociais, na saúde e no adoecimento, fatores esses que podem ou não deteriorar esse contexto de trabalho.

\subsubsection{Considerações iniciais acerca do Prazer e Sofrimento no Trabalho}

O trabalho ocupa lugar de destaque na sociedade contemporânea, tornando-se o centro na vida dos indivíduos e pode ser caracterizado como fonte de prazer e sofrimento. Várias foram as transformações ocorridas no universo do trabalho, marcados por diferentes fases históricas e modificações no sentido do trabalho, na forma de produção, na gestão de pessoas e nos direitos do trabalhador. Essas modificações não trouxeram muitos benefícios para os trabalhadores.

Para Dejours (2000), existe a falsa concepção de que a mecanização e a robotização diminuíram ou eliminaram o sofrimento no trabalho. Isso porque o que as empresas mostram são suas fachadas e vitrinas, mas por trás delas há o sofrimento dos que trabalham dos que temem não satisfazer, não estar à altura das imposições da organização do trabalho: imposição de horário, de ritmo, de formação, de informação, de aprendizagem, de nível de instrução e de diploma, de experiência, de rapidez de aquisição de conhecimentos teóricos e práticos e de adaptação à cultura ou à ideologia da empresa, às exigências do mercado, às relações com os clientes, os particulares ou o público etc.

Entretanto, Ferreira e Mendes (2001), colocam que o contexto de trabalho não determina o surgimento de uma ou outra vivência. As vivências de prazer-sofrimento ocorrem a partir da inter-relação entre a realidade concreta de trabalho e a subjetividade do trabalhador. Essas vivências coexistem segundo Mendes e Morrone (2002), na relação do trabalhador com seu trabalho e o indicador de saúde no trabalho não é a simples existência de sofrimento ou prazer, mas a diversidade de estratégias utilizadas pelos trabalhadores na tentativa de transformar situações geradoras de sofrimento em situações geradoras de prazer.

Segundo Mendes (2007), essa temática de trabalho, prazer e sofrimento inspiram o objeto de estudo da Psicodinâmica do Trabalho, a qual articula a organização do trabalho e os processos de subjetivação, que se manifestam nas vivências de prazer e sofrimento, nas estratégias de ação para medir contradições da organização do trabalho, nas patologias sociais, na saúde e no adoecimento.

A psicodinâmica do trabalho é a abordagem científica que tem se mostrado mais hábil para explicar o construto dialético prazer-sofrimento. Isso porque ela investiga principalmente 
as mediações utilizadas pelos trabalhadores, diante do confronto sujeito-realidade, específico de cada contexto de trabalho (FERREIRA; MENDES, 2003).

Segundo Mendes (2007), a psicodinâmica do trabalho é uma abordagem que está além da teoria e da pesquisa, sendo também um modo de ação na organização do trabalho. A psicodinâmica do trabalho é uma abordagem de pesquisa e ação sobre o trabalho, um modo de fazer uma análise crítica e reconstrução da organização do trabalho, que é o provocador do sofrimento. É como considerar a psicodinâmica do trabalho uma teoria crítica do trabalho, que engloba a construção/reconstrução das relações entre sujeitos/trabalhadores e realidade concreta do trabalho.

A psicodinâmica do trabalho foca nas vivências de prazer e sofrimento como dialéticas contidas em todo contexto do trabalho, bem como as estratégias usadas pelos trabalhadores para confrontar com a organização do trabalho, para manter a saúde, evitar o adoecimento e garantir a produtividade (MENDES, 2007).

Na visão de Mendes e Morrone (2002), a organização do trabalho é um dos principais antecedentes do prazer-sofrimento, a qual reflete um contexto sociocultural e econômico mais amplo. Segundo Freitas (2000), as organizações dominam e controlam seus trabalhadores de forma explícita ou por meio do "não dito" do discurso organizacional, os influenciam de alguma forma, o que gera alterações nas relações sociais que são estabelecidas dentro e fora da organização.

Desta forma, a organização do trabalho está diretamente relacionada às vivências de prazer e de sofrimento do trabalhador, a qual muitas vezes é manifestada mais em uma vivência do que em outra. Mas o conflito que surge entre a organização do trabalho e o funcionamento psíquico pode originar sofrimento, como também suscitar estratégias de mediação e também prazer. Os tópicos vivências de prazer, vivências de sofrimento e estratégias de mediação serão analisados com mais detalhes a seguir.

\subsubsection{Vivências de Prazer no Trabalho}

Um dos sentidos do trabalho é o prazer, o qual surge quando o trabalho cria identidade, permitindo que o trabalhador se torne sujeito da ação, criando estratégias, e com essas podendo dominar seu trabalho e não ser dominado por ele, embora isso nem sempre seja possível em função do poder da organização do trabalho para desarticular as oportunidades para o uso das estratégias. Essa vivência de prazer não depende do "querer", mas sim das 
condições onde o trabalho é realizado, da natureza da tarefa e do tipo de exigências que envolvem as capacidades dos indivíduos (MENDES, 2007).

Para a psicodinâmica do trabalho existe a possibilidade de vivenciar prazer mesmo em situações precarizadas, desde que a organização do trabalho ofereça condições para o trabalhador desenvolver três importantes ações: mobilização da inteligência prática, do espaço público da fala e da cooperação. Segundo Mendes (2007), a mobilização da inteligência prática pode ser caracterizada como a ruptura das regras e normas, sendo assim uma inteligência que perpassa o trabalho prescrito e funciona para atender os objetivos de produção com procedimentos mais eficazes do que os impostos pela organização do trabalho. Já o espaço público da fala seria um espaço onde as opiniões são baseadas nas crenças, desejos, valores, posições ideológicas, escolhas éticas, etc., e que são eventualmente contraditórias, podendo ser livremente formuladas e declaradas. E por último, a ação de cooperação seria a construção conjunta e coordenada para produzir uma idéia, serviço, produto comum com base na confiança e na solidariedade.

Podemos citar como exemplo de fonte de vivência de prazer no trabalho a mobilização subjetiva, caracterizada como um meio para lidar com o sofrimento, diferenciando-se assim das estratégias individuais e coletivas de defesa, já que implica a ressignificação do sofrimento, e não sua negação ou minimização (DEJOURS 1993/2004 apud MENDES, 2007).

A mobilização subjetiva é o processo onde o trabalhador se empenha no trabalho, lançando mão de sua subjetividade, da sua inteligência prática e do coletivo de trabalho no intuito de transformar as situações causadoras de sofrimento. A mobilização subjetiva possibilita a dinâmica do reconhecimento, que é definida por Dejours (2005) como um modo específico de retribuição simbólica dada ao sujeito.

O reconhecimento seria outro exemplo de fonte de vivência de prazer. Este pode ser caracterizado como o processo de valorização do esforço e do sofrimento investido para realização do trabalho, possibilitando ao sujeito a construção de sua identidade, caracterizada por vivências de prazer e realização de si mesmo. Mas em contrapartida, o reconhecimento também pode ter seu lado negativo quando passa a ser um modo de captura dos trabalhadores nas armadilhas da dominação. O trabalho exerce papel fundamental para realização do sujeito, e isso é usado pela organização do trabalho para fazer o trabalhador se empenhar na produção. A organização do trabalho promete utilizar o trabalho como forma de auto-realização, levando o trabalhador muitas vezes à exaustão em nome dessa promessa (MENDES, 2007). 
Também faz parte da vivência de prazer o uso da criatividade, a qual possibilita impressão da marca pessoal no trabalho, o sentimento de orgulho e admiração pelo trabalho realizado, tendo a aprovação da chefia e dos colegas (FERREIRA; MENDES, 2001). O sofrimento, podendo ser transformado em criatividade, tem como contribuição o benefício da identidade, o aumento da resistência do sujeito ao risco de desestabilização psíquica e somática e funciona como um promotor de saúde (MENDES, 2007).

As vivências de prazer estão relacionadas com trabalhos que são possíveis de realizarem atividades com início, meio e fim, onde o indivíduo tem a oportunidade de perceber o produto de seu trabalho. Ainda mais que isso, ter liberdade de expressão e autonomia para realizar as atividades também são fatores que podem favorecer as vivências de prazer no trabalho (FERREIRA; BARROS, 2003).

Segundo Mendes (2004), o comportamento saudável não implica na ausência de sofrimento, e sim, as possibilidades internas e externas de o indivíduo transformar o sofrimento por meio da tomada de consciência das suas causas, dos conflitos e frustrações que o geraram.

\subsubsection{Vivências de Sofrimento no Trabalho}

Ferreira e Mendes (2001) definem o sofrimento como uma vivência intensa e duradoura, na maioria das vezes inconsciente, de experiências dolorosas como angústia, medo e insegurança, oriundas do conflito entre necessidades de gratificação do indivíduo e restrição no ambiente de trabalho. Para esses autores, as vivências de sofrimento se originam nas situações adversas provenientes das dimensões da organização, condições e relações de trabalho que estruturam o contexto de produção de bens e serviços.

Essas vivências constituem indicadores de mal-estar no trabalho e manifestam-se por meio de sintomas de ansiedade, insatisfação, indignidade, inutilidade, desvalorização e desgaste, transformando assim o trabalho em algo penoso, principalmente quando a organização ignora os desejos e necessidades do trabalhador (DEJOURS, 1992; FERREIRA; MENDES, 2003).

As dimensões do contexto de condições e relações de trabalho são determinadas por fatores como tarefa, ritmo, tempo e controle do trabalho, ambiente físico, equipamentos e material oferecido pela instituição, bem como as informações disponibilizadas para realização das tarefas, comunicação e sociabilidade entre os pares e a hierarquia. O conjunto desses elementos, ao atuar de forma negativa ou restritiva, é responsável pelo desencadeamento ou 
não do sofrimento (BARROS \& MENDES, 2003). O sofrimento no trabalho pode também se manifestar por meio de tarefas arriscadas para a saúde, em condições agravadas pelas infrações das leis trabalhistas; de riscos como radiações ionizantes, vírus, fungos, amianto e horários alternados (DEJOURS, 2000).

Segundo Mendes (2007), o sofrimento surge quando não é mais possível a negociação entre o sujeito e a realidade imposta pela organização do trabalho. Esse sofrimento pode ir se intensificando à medida que a organização do trabalho não permite a subversão do trabalho prescrito em um trabalho no qual o trabalhador usa sua inteligência prática.

Tudo isso provoca não só o sofrimento do corpo, mas também apreensão e até angústia nos que trabalham. O medo da incompetência é um fator que assume relevante importância em várias situações de trabalho, principalmente em casos de acidentes ou incidentes os quais a sua origem é duvidosa. Esses casos em que os trabalhadores não têm como saber se as falhas ocorreram devido a sua incompetência ou devido a falhas no sistema, são fontes também de angústia e sofrimento (DEJOURS, 2000).

É de se esperar que o sofrimento no trabalho gere uma série de manifestações psicopatológicas. Foi, segundo Dejours (2000), para analisá-las que se realizaram estudos clínicos denominados "psicopatologia do trabalho". Uma forma que o trabalhador encontra para lidar com o sofrimento de modo a não desenvolver uma doença mental é quando este dispõe de estratégias de defesa individuais ou coletivas. As coletivas, no entanto, ocorrem somente quando há trabalho em equipe e os trabalhadores fazem parte de um grupo de operação em que o sentido é compartilhado por todos os integrantes (DEJOURS, 1992). Essas estratégias são utilizadas na tentativa de evitar o sofrimento e serão analisadas com maiores detalhes no tópico a seguir.

\subsubsection{Estratégias de mediação}

A utilização de estratégias de mediação é necessidade do trabalhador para evitar a doença mental. Então, para lidar com a dupla possibilidade de vivências originadas no contexto de trabalho, os trabalhadores fazem uso de estratégias que, conforme Ferreira e Mendes (2003) explicam, podem ser de dois tipos: de mobilização coletiva e de defesa.

As estratégias de mobilização coletivas são maneiras de agir, que tendem minimizar o custo humano negativo no trabalho, ressignificar o sofrimento e transformar o trabalho e as relações sociais em fontes de prazer. Pode-se dizer que as estratégias de mobilização coletiva funcionam como regras que supõem um acordo entre os indivíduos coletivamente, não se 
sustentando a não ser por consenso. As defesas coletivas são entendidas como formas de adaptação e, sobretudo de transformação das pressões da organização do trabalho.

As estratégias defensivas, segundo Dejours, Abdoucheli e Jayet (1994), são, na sua maioria, coletivas. Esses autores definem as estratégias como mecanismos pelos quais o trabalhador busca modificar, transformar e minimizar a percepção da realidade que o faz sofrer. Os autores apontam que a diferença entre um mecanismo de defesa individual e coletivo está no fato de que o primeiro permanece sem a presença física do objeto, que se encontra interiorizada. Ao passo que o segundo depende da presença de condições externas e se sustenta no consenso de um grupo específico de trabalhadores. Exemplos de estratégias defensivas são mecanismos de negação e/ou racionalização do sofrimento (FERREIRA; MENDES, 2003). São defesas que os trabalhadores utilizam para minimizar a percepção das pressões da organização do trabalho, que geram sofrimento. É uma atividade realizada a nível mental, já que não institui nenhuma mudança real da pressão exercida pela organização do trabalho.

Em suas pesquisas, Mendes (1996) confirma alguns desses indicadores, destacando como antecedentes das defesas as adversidades do modelo de organização do trabalho, que geram um sentimento de impotência dos trabalhadores diante do poder ideológico, econômico, tecnológico e político. Isto paralisa os trabalhadores ante as possibilidades de mudança, restando-lhes a utilização de estratégias defensivas, tais como a racionalização, a passividade e o individualismo.

Segundo a autora, a racionalização é utilizada diante da frustração para explicar de forma lógica os motivos que causam o sofrimento, tais como separação entre planejamento e execução e pela desestruturação das relações psicoafetivas com colegas; o individualismo é uma estratégia utilizada diante do sentimento de impotência e por meio dela os trabalhadores naturalizam o contexto histórico dos fatos que produzem o sofrimento. A passividade é uma estratégia contra o tédio, em função de situações de ameaça de perder o emprego e de manutenção do status quo pela empresa.

Todas essas pesquisas sobre as estratégias defensivas relacionadas ao sofrimento psíquico no trabalho levam a concluir que tais defesas são necessárias para a saúde do trabalhador, embora a condição necessária ao equilíbrio psíquico seja o trabalho um lugar de prazer, de possibilidade de o trabalhador firmar-se enquanto sujeito por meio do reforçamento da sua identidade pessoal e profissional, bem como lugar de reconhecimento, liberdade e valorização do trabalhador (BARROS \& MENDES, 2003). 
Nessa perspectiva, os autores afirmam que o predomínio da utilização das estratégias de defesa conduz à minimização do sofrimento, mas não à ressignificação e transformação dos aspectos nocivos presentes no contexto de produção, ao passo que a aplicação das estratégias de mobilização coletiva implica redução ou eliminação do sofrimento e mudança da situação de trabalho. Dessa forma, o contexto influencia as estratégias a ser adotadas e que vão prevalecer entre os trabalhadores.

Isso posto, pode-se afirmar que as estratégias de mediação são positivas à medida que protegem o sujeito contra o sofrimento causado pelas situações de trabalho geradoras de conflito, mantendo assim o equilíbrio psíquico e evitando o adoecimento. Em contrapartida, essas defesas tornam-se negativas quando alienam o indivíduo, imobilizando-o.

Cabe salientar que o primeiro tipo de estratégia se mostra muito mais adequada para garantir e preservar a saúde dos trabalhadores que as estratégias defensivas. As estratégias de defesa podem conduzir os trabalhadores à alienação e ao adoecimento, caso elas fracassem. 


\section{Metodologia}

Neste capítulo será delineado o método utilizado na pesquisa, cujo objetivo foi analisar a relação entre contexto de trabalho, as vivências de prazer e sofrimento no trabalho e as estratégias de mediação do sofrimento de Gestores de Pessoas. Incluem-se, nesta parte, uma apresentação da forma pela qual a pesquisa foi estruturada, a partir da identificação do tipo de pesquisa, de seus participantes, do instrumento e do processo de coleta de dados, técnica utilizada para sua análise e a caracterização das empresas pesquisadas.

\subsection{Tipo de pesquisa}

Utilizou-se o método qualitativo para a coleta, tratamento e análise dos dados, por ser considerado o mais adequado ao objetivo do estudo, na medida em que privilegia analisar os aspectos subjetivos e singulares de um evento no qual o indivíduo está inserido, tendo-o como ponto central. Desse modo foram investigados os sentimentos relacionados ao trabalho, a dinâmica que envolve as vivências de prazer e sofrimento no trabalho e as formas de enfrentálo.

Segundo Mendes (2007), a pesquisa para a psicodinâmica, está diretamente relacionada à clínica do trabalho, a qual privilegia a fala. A clínica do trabalho é um modo de colocar o trabalho em análise, permitindo o acesso aos processos de subjetivação, às vivências de prazer-sofrimento, às mediações e ao processo saúde-adoecimento. É a tradução do real pela escuta e pela fala, é tornar as situações de trabalho inteligíveis. Isso é desafiador, já que o real é permeado pelas resistências do saber fazer, pelas estratégias de defesa, pela inteligência prática, levando a clínica do trabalho a adotar caminhos metodológicos que sejam reveladores dessas mediações.

\subsection{Participantes da Pesquisa}

Os sujeitos dessa pesquisa são Gestores de Pessoas da III Turma de Especialização em Gestão de Pessoas do PPGA (Programa de Pós-Graduação em Administração da UnB) e foram selecionados sujeitos de outras empresas, por meio de redes de amizades. As entrevistas foram feitas com os Gestores e seus assistentes.

\subsection{Instrumento de Coleta de Dados}

$\mathrm{O}$ instrumento utilizado para coleta de dados desta pesquisa foi entrevista individual semi-estruturada e os temas abordados foram sobre as atividades desenvolvidas, as condições 
e as relações de trabalho, os sentimentos em relação ao trabalho, como é feito para dar conta/lidar/enfrentar o dia-a-dia do trabalho, como o trabalho tem afetado o comportamento e a saúde; e as demais perguntas foram feitas com base nas respostas e dentro de técnicas relacionadas ao objetivo desta pesquisa.

\subsection{Procedimento de Coleta de Dados}

As entrevistas foram previamente agendadas com os participantes e foi realizada e registrada pessoalmente pela pesquisadora. A entrevista iniciou-se por um Rapport no intuito de criar um vínculo de confiança entre o entrevistador e o entrevistado. O sucesso deste vínculo depende da atitude do entrevistador, podendo ser de acolhimento, valorização e reconhecimento do outro, ou até mesmo de distanciamento, controle e julgamento (MENDES, 2007).

Neste momento foram transmitidos os objetivos da pesquisa e do contrato psicológico de forma bastante clara. Informou-se ainda que a coleta desses dados tinha por objetivo, uma pesquisa acadêmica que visava identificar os sentimentos dos trabalhadores e suas conseqüências em relação à dinâmica prazer-sofrimento no trabalho; que as respostas seriam analisadas em conjunto com as informações fornecidas por outras pessoas, inclusive de outras empresas, destacando o caráter sigiloso; que a fita seria destruída após sua transcrição, caso o participante permita a gravação; e que não era necessário a identificação do participante e da organização em que trabalha.

Após isso, utilizou-se a técnica da Associação Livre, com o objetivo de evocar conteúdos referentes ao trabalho que não estão necessariamente conscientes, é levar o entrevistado a se escutar, a tomar consciência do conteúdo falado (MENDES, 2007). Para isso, solicita-se ao entrevistado falar o que lhe vem a cabeça quando ouve a palavra trabalho e o entrevistador deverá centrar-se em questões abertas, permitindo a fala livre dos trabalhadores.

\subsection{Análise dos dados}

Para fins de análise, as entrevistas foram gravadas (com autorização dos entrevistados) e transcritas na íntegra, considerando que são a fala do sujeito, o dado essencial para apreensão do objeto e interpretação dos dados. Depois de transcritas, as entrevistas foram submetidas à análise utilizando a ANS - Análise dos Núcleos e dos Sentidos, visando a apreender os sentidos que constituem o conteúdo do discurso dos sujeitos informantes através do que chamamos de núcleos de significação. 
Segundo Mendes (2007), a ANS consiste no desmembramento do texto em unidades, em núcleos de sentido formados a partir da investigação dos temas psicológicos sobressalentes do discurso.

Desta forma, os dados foram agrupados em categorias pelos critérios de semelhança, lógica e pertinência dos conteúdos, com base nos três elementos das condições de trabalho: organização, relações socioprofissionais e subjetividade e trabalho. Posteriormente, foram constituídas categorias-síntese e elaboradas definições para cada categoria, discutidas e interpretadas pelo pesquisador com base no referencial teórico e nas questões de pesquisa propostas.

\subsection{Caracterização das Empresas Pesquisadas}

Esta pesquisa foi desenvolvida em três empresas do ramo de supermercados e farmácia, as quais denominarei de empresa A, B e C. As três empresas tem em comum o fato de serem empresas familiares, vinculadas ao comércio, com rigorosas cobranças focando nos resultados/lucros e decisões sempre centralizadas nos diretores.

A empresa A é uma rede de supermercados que foi fundada em 1979. Essa rede tem lojas nas cidades de São Paulo (20 lojas), Belo Horizonte (6 lojas) e Brasília (4 lojas). Nas lojas de Brasília tem aproximadamente 350 funcionários. A empresa pesquisada é uma empresa familiar e o foco do dono da empresa é o horti-fruti. A pesquisa foi realizada em uma das lojas de Brasília

A empresa B é uma rede de farmácia que tem lojas em Brasília e Goiânia totalizando em média 105 lojas em funcionamento, mas com expectativas de abrirem mais filiais. Em Brasília existem 40 lojas e a pesquisa foi realizada em uma dessas filiais daqui de Brasília. A empresa também é familiar e tem como foco a venda de remédios e produtos de perfumaria.

A empresa C é uma empresa especializada em produtos alimentícios, fundada em 1988, em Brasília, Distrito Federal. É uma empresa de grande porte, que integra uma rede de Supermercados. Atualmente, essa rede constitui-se de três lojas, com aproximadamente cento e sessenta funcionários no total. A pesquisa foi realizada em uma das lojas que integram essa rede, sendo ela composta por noventa e cinco funcionários, distribuído nos vários setores da empresa. 


\section{Resultados e Discussão}

As entrevistas revelaram informações sobre o perfil dos participantes, sobre as vivências de prazer e de sofrimento e as estratégias de mediação que os mesmos fazem uso. Os resultados encontrados neste trabalho refletem opiniões e percepções dos entrevistados extraídas das verbalizações feitas nas entrevistas.

Sem essa escuta da fala, não seria possível investigar os elementos reveladores do latente encobertos pelos elementos falados e descritos no discurso manifesto. A importância da fala do trabalhador é fundamental para a realização de pesquisas na clínica do trabalho, assim como para compreender o prazer-sofrimento e a saúde do trabalhador (MENDES, 2007).

As verbalizações foram categorizadas e serão descritas nesta seção, juntamente com reflexões embasadas no referencial teórico da Psicodinâmica do Trabalho, exposto anteriormente neste estudo.

Os resultados das entrevistas permitiram a identificação de três categorias:

- Organização do Trabalho;

- Relações Socioprofissionais e

- Subjetividade e Trabalho.

Estas categorias serão apresentadas, definidas, discutidas e comparadas de acordo com a categoria profissional dos entrevistados.

\subsection{Organização do Trabalho}

Por organização do trabalho entende-se a "divisão do trabalho, conteúdo da tarefa, o sistema hierárquico, as modalidades de comando, as relações de poder, as questões de responsabilidades" (DEJOURS, 1987 apud MENDES; MORRONE, 2002). As formas como estes temas se apresentam no discurso dos entrevistados será descrita a seguir.

\subsubsection{Papel da Área de Gestão de Pessoas: "a área de RH dificilmente vai se transformar em Gestão de Pessoas"}

A área de Gestão de Pessoas nas três empresas pesquisadas demonstrou poucas mudanças, estão muito vinculadas à idéia da área como de Recursos Humanos e Departamento de Pessoal, realizando tarefas burocráticas de Recrutamento e Seleção, e Treinamentos, em sua grande maioria, vinculados às normas e metas que devem ser 
alcançadas nas empresas. A empresa $\mathrm{C}$ é a que está mais próxima de conseguir implantar a área de Gestão de Pessoas dentro da organização, porque está vinculada a todos os setores da organização com objetivo do desenvolvimento profissional e pessoal dos trabalhadores e priorizam muito o respeito ao trabalhador. Os entrevistados dessa empresa relataram que os treinamentos já realizados focam assuntos além do burocrático. Já as empresas A e B, relataram que nunca escutaram sobre o tema prazer e sofrimento no trabalho e que inclusive nos treinamentos que participaram o assunto nunca foi apresentado. Eles emitem ainda opiniões sobre a importância de abordarem o tema Prazer e Sofrimento até então desconhecidos.

Os profissionais entrevistados dessas três empresas deparam-se num contexto de contradições, como a de gerir dilemas e tensões e ainda trazer resultados para a organização. Mas ela não pode resumir-se somente a isso, a área de Gestão de Pessoas tem que se preocupar mais com a representação simbólica de seus benefícios, da entrega de vida quase absoluta que o trabalho acaba consumando. Operar por resultados, que é a máxima em todos os setores das três organizações pesquisadas, não o deveria ser para a área de Gestão de Pessoas, uma vez que ambicionar resultados favoráveis, alcançar metas, garantir a produtividade podem significar falhas no decorrer do processo que resultado algum pode justificar.

"A área de Gestão de Pessoas está compartilhada com todos os setores da organização em prol do progresso das pessoas e também da organização. Os gestores de cada setor são treinados a liderar as pessoas de forma que estas possam ser formadas para assumir outras posições no futuro. O respeito às pessoas e a preocupação com o bem-estar é algo muito levado a sério" (gestor da empresa C).

“A função da área é orientar as pessoas para o alcance dos objetivos individuais das equipes e da empresa. Trabalhar com ações voltadas para a eficácia da comunicação interna, da administração participativa e da melhoria da qualidade de vida” (gestor da empresa C).

"Vejo como uma área importante que está sendo estruturada aos poucos, pois não tínhamos definidos na organização o papel da área de gestão de pessoas. Evoluiu muito e sei que vai crescer muito mais" (assistente da empresa C).

“A área de Gestão de Pessoas é pouco desenvolvida e pouco enxergada. A área de RH 
dificilmente vai se transformar em Gestão de Pessoas. Por isso que eu falo, como o papel de Gestão de Pessoas não é enxergado, não tem jeito" (gestor da empresa A).

"A área de Gestão de Pessoas é a área que mais tem competência para diminuir sofrimento e aumentar o prazer dos funcionários no trabalho" (gestor da empresa A).

"Quando as pessoas estão com algum problema, costumam buscar a área de Recursos Humanos, né?" (assistente da empresa A).

"Procuro chamar a pessoa para ver se ela me expõe o que ela está passando. Procuro saber para procurar ajudar aquela pessoa. Acho que essa é a função de nós, gerentes" (gestor da empresa B).

"O papel da área de Recursos Humanos teria que ser o de escolher melhor os gerentes que estão ali. Acho que é o contato direto de todos os funcionários, que faz com que a loja cresça, atinja metas. Acho que essa escolha, essa característica do profissional tinha que ser mais bem avaliada" (assistente da empresa B).

"Os treinamentos vão além de instruções burocráticas do "como fazer", mas abrange também o desenvolvimento pessoal do funcionário, procurando estabelecer momentos de alegria, bem-estar e qualidade de vida fora e dentro do trabalho" (gestor da empresa C).

"Nunca tive treinamento sobre esse tema, era mais emoção/razão. Era relacionado com outras coisas" (assistente da empresa A).

"Não me lembro de participar de treinamentos que abordaram esse tema. Só na especialização que estou fazendo. Eu acho importantíssimo, apesar de eu achar que os donos da empresa não tem interesse algum sobre esse assunto. Eles visam só o lucro” (gestor da empresa A).

"Os donos da empresa não tem interesse nenhum em falar sobre Prazer e Sofrimento no Trabalho. Porque isso gera discussão demais. Eles querem ganhar o dinheiro deles e pronto" (gestor da empresa A). 
“Interessante abordar esses dois temas no trabalho, porque ai a gente vê os dois lados, que é o lado que te dá prazer e o lado que dá mais sofrimento, né? Mas nunca tivemos treinamentos sobre esse assunto” (gestor da empresa B).

"Eles preocupam com treinamentos, com palestras de interesse deles. Acho que se tivesse alguma coisa sobre prazer e sofrimento ia melhorar muito o ambiente de trabalho, muito mesmo" (assistente da empresa B).

Em toda a literatura que trata das mudanças por que passa o ambiente empresarial, um fator é reconhecido consensualmente como fundamental para o êxito dos processos de mudança: a capacidade de mobilizar pessoas (RUAS, 2004). Apesar de tardia, esta consciência da importância das pessoas reflete-se na transição do termo Administração de Recursos Humanos - ARH para Gestão de Pessoas. A sutil diferença de nomenclatura traz no seu bojo a grande amplitude que passa a ter esta área, com novas dimensões e complexidades.

Entretanto, faz-se necessário esclarecer que, mesmo reconhecendo, teoricamente, que o termo Administração de Recursos Humanos apresente uma conotação mecanicista e que a sua substituição por um conceito mais amplo facilita a compreensão da significância que esse construto adquiriu nos últimos anos, as empresas pesquisadas não tem ainda a compreensão do real valor da área. Elas vinculam um discurso que a área de Gestão de Pessoas tem que facilitar ou acompanhar a integração dos funcionários, mas na prática operam pelo desenvolvimento de processos de exclusão e de auto-exclusão (LIMA, 1994).

\subsubsection{Conteúdo da tarefa: "no dia-a-dia meu trabalho é rotineiro"}

Há relatos de insatisfação dos trabalhadores da empresas $\mathrm{A}$ e $\mathrm{B}$ com relação às tarefas executadas, as quais se apresentam com conteúdos repetitivos, monótonos, dificultando assim o trabalhador ter uma visão positiva do que faz o que gera um sentimento de que seu trabalho não tem sentido e significado, que é limitado e que isso não faz parte da sua subjetividade. A organização em que trabalham são rígidas, com poucos conteúdos significativos do trabalho e com pouca possibilidade de mudá-lo, devido à resistência por parte dos diretores.

$\mathrm{Na}$ empresa $\mathrm{C}$ o trabalho é caracterizado com gratificante, não rotineiro, porém burocrático porque existem algumas limitações vindas da diretoria como a demora nas decisões, falta de investimento para alguns projetos ou até mesmo sua rejeição, o que acaba dificultando o trabalho dos gestores dentro da empresa. Existem limitações também relacionadas à assistente nessa empresa porque o gestor não delega funções da área estratégica 
para seu assistente pelo fato de que este ainda não está pronto para assumir tal função, o que acaba sobrecarregando o gestor.

"Hoje eu me sinto engessada, impotente. Eu estou completamente sem perspectivas de crescimento, sem perspectiva de cultura. A cultura não me diz que eu posso implantar alguma coisa positiva que vá gerar um fruto” (gestor da empresa A).

"No dia-a-dia meu trabalho é rotineiro. Tem a parte de Recrutamento e Seleção, a de Treinamento e a de entrevistas admissionais. São atividades que preciso executar e estão vinculadas ao Departamento de Pessoal. São atividades bem burocráticas” (gestor da empresa A).

"Todos os dias eu procuro organizar tudo da mesma maneira. Hoje já começo a organizar as coisas de amanhã” (gestor da empresa B).

"Quando eu levanto fico pensando já no final do dia, porque sei que quando chegar lá na empresa terei que fazer sempre a mesma coisa e isso me dá um desanimo" (auxiliar da empresa B).

"A gente não consegue fazer sempre o que nos dá paixão, tem sempre uma rotina que traz uma ansiedade pra gente, traz aquele sentimento mais negativo” (gestor da empresa A).

"O meu trabalho é muito gratificante. Nem sempre tudo sai da maneira como gostaríamos, pois infelizmente enfrentamos barreiras como falta de investimento para algum projeto, às vezes rejeição para implantação de projetos, falta de apoio da alta direção para mudar alguns critérios já definidos na organização” (gestor da empresa C).

"Meu trabalho não segue uma rotina diária. É um trabalho muito dinâmico, desenvolvo pesquisas diversas na área de gestão de negócios, vendas, resultados" (assistente da empresa C).

"Meu setor é o RH, onde trabalhamos eu e uma auxiliar de DP. O serviço burocrático de DP é terceirizado e a auxiliar ajuda nesta parte burocrática dentro da empresa. Na parte estratégica de RH eu sou a pessoa responsável para executar todo o trabalho, o que muitas 
vezes me sobrecarrega. Ainda não me sinto segura em delegar para a assistente a parte estratégica de RH, pois tal trabalho exigem habilidades, competências, as quais ela ainda não está preparada para executar” (gestor da empresa C).

As tarefas são modos operatórios cognitivos, procedimentos e instrumentos utilizados pelos trabalhadores para produzir algo. A realização da tarefa não está desvinculada do sujeito que realiza e do contexto no qual está inserido. A forma como o trabalho é organizado permite a realização de tarefas com conteúdos significativos ou não, bem como influencia o sentido particular que a tarefa assume para cada trabalhador.

O conteúdo significativo da tarefa em relação ao sujeito representa o grau de satisfação que o trabalho assume em termos de evolução pessoal, aperfeiçoamento e status social do posto de trabalho que ele ocupa, bem como representa os investimentos simbólicos que o sujeito destina à tarefa. A atribuição dos símbolos será realizada de acordo com os gestos, investimentos físicos, cognitivos e psíquicos, instrumentos e a atmosfera na qual a tarefa é desenvolvida (Dejours, 1987 apud MENDES; MORRONE, 2002).

\subsubsection{Regras e Autonomia: "todo mundo tem que seguir as normas que nos são colocadas"}

As regras nas empresas pesquisadas são constantemente acompanhadas e cobradas. $\mathrm{Na}$ realização das tarefas, o trabalhador das empresas A e B já vai desmotivado e com o sofrimento latente por fazer coisas que eles julgam desnecessárias ou até mesmo invasivas, como controlar se o cabelo do trabalhador está bem lavado, fazer reuniões periódicas onde muitas vezes nem pauta tem e acabam fazendo por obrigação mesmo.

Existe muita cobrança por parte da diretoria com relação a vendas, bater metas, cumprir as normas, cuidar da aparência, realizar os processos de contratações, etc. São atividades muito voltadas aos resultados.

Nota-se a falta de autonomia dos entrevistados nessas empresas, pois os funcionários têm que fazer aquilo que é determinado pela diretoria, onde as decisões ficam centralizadas somente neles, situações comuns em empresas familiares.

$\mathrm{Na}$ empresa A houve relatos em que realizam o processo de Recrutamento e Seleção sem a mínima autonomia, pois sabem que no final do processo quem decidirá se a pessoa será contratada ou não é a própria diretoria, colocando, muitas vezes, os parentes. Isso gera muito sofrimento para quem trabalha na área de Gestão de Pessoas, porque percebe que todo o seu trabalho ficará comprometido. 
"Tenho que fazer reuniões, que inventar reuniões para fazer periodicamente, mesmo que não tenha o que falar, mas tenho que fazer porque a diretoria manda" (gestor da empresa A).

"Todo mundo tem que ter a unha bem feita, pintada, mas ninguém sabe quanto vale quanto custa, como faz uma unha. Só quer saber de falar: você tem que ser assim, você tem que rir quando está com dor de barriga por exemplo” (assistente da empresa B).

"Cada loja tem uma meta interna que vira uma porcentagem e que é da loja e não da empresa em geral. Essas metas têm uma adequação, todo mês eles aumentam, do tanto que é suportável" (assistente da empresa B).

"Você tem que forçar o máximo o cliente levar alguma coisa. Não pode deixar ele ir embora rápido, tem que andar com ele, mostrar as promoções. Eles tem uma política assim: se entrou na loja pra perguntar o preço, vai levar pelo menos uma aspirina" (assistente da empresa B).

"Temos normas de atendimento, por exemplo: você tem que sorrir, você tem que pentear o cabelo, você tem que fazer as unhas, você tem que ser educado, falar, por favor, muito obrigado" (assistente da empresa B).

"A gente não tem uma reunião, uma palestra ali sem pauta. E quem faz essa pauta são líderes que mandam passar só coisas ligadas às normas” (gestor da empresa B).

"Uma vez por semana são feitas reuniões para discussão de metas e como está o desempenho destas" (assistente da empresa C).

"Há sempre uma agenda a cumprir, pois trabalhamos com prazos determinados e temos que estar sempre prontos a atender os clientes satisfatoriamente” (assistente da empresa C).

"Quem trabalha no comércio, todo vendedor tem sua meta. Conforme a função da pessoa é estipulada uma meta para ela bater diária e mensal" (assistente da empresa C).

"Como a gente trabalha com vendas, sempre tem aquela ambição de vender e a gente procura passar para os vendedores aqui uma missão sadia, mas uma missão sadia e não 
aquela de ambição” (gestor da empresa B).

"Existe um colaborador que todo mês ele bate a meta, com certeza ele vai ser premiado por aquilo e aqui a gente procura fazer as premiações por porcentagem, o colaborador tem que aumentar sua venda mês a mês para ser premiado, né?" (auxiliar da empresa B).

"Esse processo de seleção é um fracasso. Várias vezes as pessoas não eram aprovadas no processo seletivo comigo e a diretoria colocava essas pessoas mesmo assim. Principalmente gente da família” (gestor da empresa A).

"Eu vejo pelo meu chefe aqui que é só a família dele que trabalha aqui. Então eu entendo que para ele ter familiares aqui é uma defesa. Não é porque ele é bonzinho" (gestor da empresa A).

A autonomia, segundo Ferreira e Mendes (2003), é um dos indicadores de prazer no trabalho por possibilitar a utilização do estilo pessoal do funcionário no trabalho. Assim, a forma como estes profissionais percebem esta autonomia limitada pode definir se será um fator que contribuirá ou não para as vivências de prazer e bem-estar, que são um processo dinâmico que depende da interação entre a subjetividade do trabalhador e o contexto de trabalho (FERREIRA; MENDES, 2003).

Desta forma, o sofrimento do trabalhador pode se intensificar à medida que a organização do trabalho não permite a subversão do trabalho prescrito em um trabalho no qual o trabalhador usa sua inteligência prática, ou seja, uma organização do trabalho suficientemente flexível que absorva a criatividade, variabilidade no modo de fazer as tarefas e a subjetividade. As dificuldades dos que fazem a gestão da organização do trabalho geram maior sofrimento aos trabalhadores por não haver margem de liberdade para que utilize sua inteligência prática, sua inventividade, que seria um dos caminhos para a transformação do sofrimento (MENDES, 2007).

\subsection{Relações Socioprofissionais}

As relações socioprofissionais são os relacionamentos interpessoais estabelecidos no ambiente de trabalho. Mendes (2004) relata que o suporte das relações socioprofissionais é um dos indicadores de prazer no trabalho, e auxilia o trabalhador na dinâmica de evitação do sofrimento e do adoecimento e da manutenção da saúde. 


\subsubsection{Chefia: "eu nunca fui reclamar com meu chefe porque sabia que não ia resolver nada"}

Os trabalhadores das empresas A e B relataram que são controlados por parte da chefia, sentem-se inibidos em opinar e fazer solicitações e ainda, não podem contar com o suporte dos chefes. Afirmam que estes ficam muito presos às regras e às ordens dos diretores e não dão abertura para nenhum tipo de solicitação e/ou mudança. Relatam ainda que alguns chefes são muitos "despreparados" para o cargo que ocupam, não sabem conversar, são grosseiros e alguns possuem baixo nível de conhecimento intelectual. Já na empresa $\mathrm{C}$ há relatos de liberdade de opinar ou até mesmo conversar com a chefia que está sempre aberto ao diálogo, mas as decisões são centralizadas nele, o que compromete o andamento do trabalho conforme verificado nas outras empresas.

"Porque a cultura é uma cultura digamos, provinciana mesmo, as pessoas gostam de te controlar, você é minha subordinada, eu tenho que te controlar porque se vier outro, começar a colocar coisas na sua cabeça eu não vou conseguir mais te controlar" (gestor da empresa A).

"As chefias não vê muito que acontece, preocupar, saber, conversar. São mais ordens, normas que tem que ser seguidas" (assistente da empresa B).

"Porque eles são muitos despreparados. Grosseiros, mal educados, semi-analfabetos, escrevem coisas absurdas, grotescas" (assistente da empresa B).

“A diretoria sempre procura fazer reunião uma vez por mês com os gerentes e quando o gerente volta pra loja passamos tudo que é passado para gente é passado pros colaboradores" (gestor da empresa B).

"Meu chefe é muito inteligente, tem uma visão empreendedora surpreendente, é muito compreensivo, respeitador e está sempre disposto, aberto a qualquer tipo de conversa, está sempre aberto ao diálogo. Existe uma grande dependência em relação a ele para que seja tomada as decisões, isso muitas vezes atrapalha o andamento do trabalho" (gestor da empresa C).

Segundo Mendes (2007), o trabalho possibilita aprender sobre um fazer específico, 
criar, inovar e desenvolver novas formas para execução da tarefa, bem como são oferecidas condições de transformação do trabalho, interação com os outros e de socialização.

As relações sociais como as de poder, por exemplo, são exercidas diariamente nas empresas onde os objetivos devem ser cumpridos e as metas são sempre estabelecidas. $\mathrm{O}$ sistema de autoridade, constituído pelos subsistemas de controle de pessoal e controle burocrático objetiva integrar os empregados às metas formais da organização, fazendo-a funcionar como uma máquina, padronizando os comportamentos individuais dos influenciadores (ZANELLI; BORGES-ANDRADE; BASTOS, 2004).

\subsubsection{Equipe: "tem gente que chega e já quer ser grande"}

O relacionamento interpessoal na equipe foi ressaltado pelo assistente da empresa A e pelo gestor da empresa B como um bom relacionamento e que a consideram uma família, prezam muito pela comunicação, em saber lidar com as diferenças e acima de tudo, conseguir separar os problemas pessoais dos profissionais. $\mathrm{O}$ gestor da empresa $\mathrm{C}$ também preza muito pela comunicação e integração no trabalho que executa junto com seu assistente.

"Olha o trabalho é uma familia, né?Eu acredito que a comunicação na equipe é essencial e você tem que saber lidar com as pessoas que às vezes não tem o mesmo perfil que você. Então a gente tem que saber dosar e ceder também quando é necessário" (assistente da empresa A).

"Você tem que saber separar os momentos que você não está bem e ver que você ali é um profissional e não pode descontar em outras pessoas que nada tem haver com isso" (assistente da empresa A).

“Chego aqui me dou bem com todo mundo. Consigo conciliar meu serviço com as coisas só daqui mesmo" (gestor da empresa B).

“A gente procura trabalhar em equipe, né? Você trabalhando em equipe, sempre sendo amigo do outro, nunca tendo adversidade. Por mais que você procure trabalhar em equipe sempre surge uma adversidade, sempre surge uma pessoa ali que não vai com a sua cara, mas você tem que saber levar, né?” (gestor da empresa B).

"Na nossa equipe procuramos sempre manter o clima saudável” (gestor da empresa B). 
"O nosso trabalho é integrado e a comunicação é primordial no nosso setor" (gestor da empresa C).

Em contrapartida, o gestor da empresa A e o assistente da empresa B vêem sua equipe de trabalho como um ponto negativo. Alguns relatam que a convivência é difícil, reclamam de pessoas muito fechadas em receber informações, de pessoas que não se preocupam com o outro, não se tratam com igualdade, não querem compartilhar informações e tem muita fofoca nas equipes.

"Eu achei que uma pessoa da minha equipe tivesse mais abertura pra receber informações, para desenvolver as coisas e não foi isso que obtive. Eu obtive uma resistência tão grande no sentido do conhecimento que eu quis transmitir que acabou gerando uma cisão" (gestor da empresa A).

"Porque no nosso ramo o que acontece muito é uma pessoa que é técnica, que conhece aquele determinado produto e que vai ser encarregado ou vai ser gerente sem ter uma noção do que é coordenar. E ai eles ficam perdidos. Tem dificuldade com as pessoas e gera uma necessidade muito grande de formá-los, apesar também dos gerentes, que é a cúpula maior, não me ajudarem em nada disso, porque eles mesmos não se submetem a essa rotina" (gestor da empresa A).

"Pra você chegar a ser grande você precisa galgar alguns degrauzinhos. E aí a pessoa na ansiedade de ser grande, quer derrubar os outros e acaba com o grupo inteiro" (gestor da empresa A).

"Então aqui eles tratam a faxineira muito mal. As pessoas a humilham e não percebem que o trabalho dela é fundamental para todos. Mas as pessoas não querem nem saber" (gestor da empresa A).

"Na equipe tem muita conversinha, muita fofoca. As pessoas têm muita resistência com a diretoria" (assistente da empresa B).

Machado (1998) afirma que a equipe de trabalho não é caracterizada por se tratar de um conjunto de pessoas, mas pela dinamicidade presente nas relações mantidas entre elas, 
assim como na execução das tarefas, que estão orientadas para a consecução de um objetivo determinado.

Mas o trabalho em equipe é difícil. Para começar, uma equipe não tem uma "mente" independente dos seus integrantes, não tem a mesma capacidade de ação que um indivíduo. Nem sempre o trabalho em equipe é a melhor opção, pois existem circunstâncias que pedem soluções diferentes. Determinadas metas demandam pelo trabalho em equipe, outras, pelo individual. E há, ainda, outro gênero de meta que, para ser plenamente atingida, exige conjugar as duas opções. Trabalhar em equipe é uma competência e, como tal, pode ser aprendida e aprimorada, mas isso não significa que todas as pessoas tenham, a priori, o perfil adequado para o trabalho em equipe (SACOMANO; ESCRIVAO, 2000).

\subsubsection{Reconhecimento: "o melhor da minha loja eu vou premiar com uma caixa de bombom"}

Os entrevistados da empresa $\mathrm{B}$ relataram que os funcionários dessa empresa são reconhecidos através de premiações, bônus, parabenização sempre que cumprem as metas, independente da forma com que essa foi alcançada. Isso remete à idéia de que só é reconhecido aquele que trás lucro pra empresa, vendo somente a parte do processo e não o todo. Nem sempre o que bate a meta é o melhor, mas com certeza o que vendeu mais. Já o assistente da empresa $\mathrm{C}$ vê o sistema de recompensa (bônus) adotado pela empresa como influenciador no surgimento de casos de Sofrimento no Trabalho.

"Além de a empresa incentivar a gente elogia aquele que foi bem. A gente procura sempre incentivar nossos vendedores. Aqui todo mundo que bate meta a gente chega, parabeniza, se possível a gente dá um brinde ou então uma coisa que agrade e aumente o ego daquela pessoa" (gestor da empresa B).

"A empresa sempre procura premiar, trabalhar em organização para que tudo venha correr bem” (assistente da empresa B).

"Porque nem sempre o melhor vendedor é o que vendeu mais. Às vezes ele se dedica tanto e não consegue atingir e o outro que passa rasteira, que passa na frente, é fofoqueiro, acaba ganhando. E o gerente mantém umas pessoas que atinge meta mesmo tendo qualquer outra característica negativa, porque ele tem um retorno financeiro, porque tudo gira num esquema 
de dinheiro. Infelizmente!" (assistente da empresa B).

"Os bônus podem caracterizar como uma forma de competição e assim um determinado funcionário ganha enquanto o outro perde e se ele só perde pode causar grande sofrimento por não atingir o resultado espertado" (assistente da empresa C).

Na empresa $A$, nota-se uma divergência em relação ao reconhecimento. A assistente sente-se realizada e satisfeita com o trabalho que executa já a gestora sente-se desmotivada e sem prazer para expor suas idéias argumentando que elas não são ouvidas, que não há reconhecimento da qualidade do seu trabalho, dos esforços, das angústias, das dúvidas, decepções e desânimos que emergem no dia-a-dia do trabalho. Isso ocorre porque a assistente lida diretamente com seu gestor e que reconhece seu trabalho; já o gestor lida com os diretores, os quais não reconhecem o seu trabalho.

"Quando eu vejo as coisas que foram realizadas eu fico satisfeita com o resultado. Que a gente vê que está andando, que está fluindo as coisas que a gente planeja que está tendo resultado, então eu fico satisfeita" (assistente da empresa A).

"Eu não tenho motivo, eu não tenho prazer em mostrar as minhas idéias hoje para pessoas que eu sei que não vão dar o maior valor. Eu poderia dar muito mais. Eu já tentei mudar a forma de fazer as coisas, mas não obtive a menor aprovação. Por isso eu não faço mais nada. Joguei o pano" (gestor da empresa A).

"Eu não vou ficar brigando com um monte de gente, um monte de homem machista para mostrar uma idéia minha." (gestor da empresa A).

Segundo Mendes (2004), o reconhecimento do trabalho é um dos indicadores de bemestar e prazer no trabalho, e Dejours (2004) considera-o como um dos fatores estruturantes da personalidade no trabalho. Assim, a percepção do crescimento do reconhecimento de suas atividades por parte da sociedade é um fator que tende a tornar-se um indicador de prazer no trabalho para estes funcionários.

Ao contrário disso, quando o reconhecimento não acontece o indivíduo sente como se o trabalho dele tivesse sido em vão, acreditam na idéia de que não trouxeram nenhuma contribuição à organização do trabalho. Assim, eles não podem gozar dos benefícios do 
reconhecimento de seu trabalho nem alcançar assim o sentido de sua relação para com o trabalho. Ele se vê conduzido ao seu sofrimento e somente a ele. Segundo Dejours (2000), sofrimento absurdo, que não gera senão sofrimento, num círculo vicioso e dentro em breve desestruturante, capaz de desestabilizar a identidade e a personalidade e levar à doença mental.

\subsection{Subjetividade e Trabalho}

Esta categoria refere-se ao modo como os trabalhadores interagem com o trabalho e com as situações por ele impostas.

\subsubsection{Estratégias de Mediação: “eles vão se sujeitando a umas coisas para poder conquistar".}

Como estratégia de defesa para tentar lidar com as contradições e conflitos vivenciados no processo de prazer e sofrimento no trabalho, foi detectado que os participantes das três empresas pesquisadas fazem uso da racionalização, uma vez que tenta evitar ou eufemizar o sofrimento, agindo com indiferença, passividade e conformidade. A seguir, encontra-se respectivamente, as verbalizações de trabalhadores que passaram por esse processo:

"Eu estou numa tranqüilidade, assim, eu não me exijo muito. Estou dando o que eu acho que a empresa espera de mim e estou mantendo isso, mas sei que poderia dar muito mais" (gestor da empresa A).

"Cabe a mim administrar as horas conturbadas, ficar nervosa, estressada não vai resolver somente piorar" (assistente da empresa $\mathrm{C}$ ).

"Sempre digo: se eles querem assim, se eles pensam assim eu não vou discutir com eles, vou simplesmente seguir o que eles mandam até o dia que eu achar alguma coisa melhor que isso aqui" (assistente da empresa B).

"Tem coisas que dá pra você resolver malhando, caminhando no parque todo dia, fazendo coisas que te dão prazer" (gestor da empresa A).

"Eu sempre tento tirar o lado bom das coisas para conseguir melhorar. Eu acredito que as 
coisas acontecem sempre pra gente poder crescer" (gestor da empresa A).

“Antes, se era um dia ruim, ou se tinha algum problema com outro funcionário eu já me envolvia nisso. Eu ficava estressada também. Agora eu estou conseguindo separar melhor as coisas, não me envolver tanto, porque não é problema meu” (assistente da empresa B).

"Muitas pessoas quando começam a trabalhar pensam que a empresa tem que se adaptar ao jeito dela, mas na verdade não, nós é que temos que nos adaptar a ela. Temos que nos adequar a ela para mantermos o nosso emprego" (gestor da empresa B).

Como estratégias típicas de negação, ou seja, negação do próprio sofrimento e do sofrimento alheio pela naturalização do mesmo e das injustiças e por comportamentos de isolamento, desconfiança e exarcebação do individualismo (FERREIRA; MENDES, 2003), destacam-se as verbalizações a seguir do assistente da empresa B:

"Você tem que fingir muito. Fingir pro seu chefe, pra cliente. Fingir pra você mesma para permanecer na empresa. São coisas que a gente faz pra poder manter".

"Mesmo ele passando na frente dos outros nas vendas, pensando somente nele, no final das contas se ele vender mais ele é o melhor vendedor e leva a melhor".

A organização do trabalho participa ativamente das vivências de prazer e de sofrimento do trabalhador, muitas vezes se manifestando mais em uma vivência do que em outra. O conflito que surge entre a organização do trabalho e o funcionamento psíquico pode originar sofrimento como também suscitar estratégias de mediação. A utilização de estratégias de mediação é uma necessidade do trabalhador para evitar a doença mental. Então, para lidar com a dupla possibilidade de vivências originadas no contexto de trabalho, os trabalhadores fazem uso dessas estratégias (MENDES, 1996).

Essas estratégias podem ser de negação e/ou racionalização do sofrimento (FERREIRA; MENDES, 2003). São defesas que os trabalhadores utilizam para minimizar a percepção das pressões da organização do trabalho, que geram sofrimento. É uma atividade realizada a nível mental, já que não institui nenhuma mudança real da pressão exercida pela organização do trabalho. 


\subsubsection{Realização Profissional: "me sinto realizada com o trabalho que executo"}

Os entrevistados relataram sentir-se realizados profissionalmente e que esse resultado foi fruto de esforços e chances que a empresa deu, gerando gratidão destes para com a empresa. Outro trabalhador coloca a tarefa que executa como a realização de um sonho.

"Sinto-me realizada em contribuir com os meus conhecimentos e por contribuir com o crescimento da empresa" (assistente da empresa C).

"Gosto do que faço aqui. Trabalhei muito para chegar aonde cheguei. Isso tudo se deve ao meu esforço e às chances que a empresa me deu. Sou muito grato a essa empresa” (gestor da empresa B).

"Nessa organização pude crescer profissionalmente, tenho a oportunidade de fazer o que gosto. A organização valoriza o meu trabalho” (gestor da empresa C).

"Quando fazia faculdade sonhava com esse emprego que tenho hoje. Já trabalhei em outros lugares, mas nenhum se compara com o que eu faço aqui. Sou muito satisfeita com o cargo que eи осиро e com as funções que eu desempenho” (assistente da empresa A).

Ao contrário disso, outros entrevistados relataram que não estão realizados profissionalmente. Alguns assistentes sentem-se insatisfeitos pela falta de perspectiva de crescimento dentro da empresa. Já o gestor da empresa A reclamou que a área de Gestão de Pessoas não tem muita credibilidade na organização e consequentemente seu trabalho também não. Relatou ainda que não consegue implantar mudanças e que não concorda com a diretoria, cuja visão é a de que as pessoas devem ser tratadas como "custos" e o tratamento a elas como "recurso". A área de Gestão de Pessoas deveria ser a área que mais precisaria trabalhar a questão de prazer e sofrimento no trabalho, mas foi observado que os próprios gestores de pessoas sofrem com as contradições organizacionais não tendo a chance de abordar assuntos como esses e mais que isso, não sabe lidar quando isso ocorre no ambiente de trabalho.

"Temos que procurar fazer o nosso trabalho do jeito que a empresa quer, não conseguimos implantar nada aqui” (gestor da empresa A).

"Então, quando essa cultura não te mostra um caminho, você vê que não consegue crescer" 
(gestor da empresa A).

"Não adianta fazer projetos, apresentar a diretoria porque não muda. Eles pensam sempre do mesmo jeito. Isso me deixa muito decepcionada, porque se conseguíssemos implantar algumas coisas aqui, melhoria muito" (gestor da empresa A).

"Ah, eu nunca vou poder crescer nessa empresa" (assistente da empresa B).

"Meu cargo é um e eu não tenho mais pra onde subir. Eu não tenho planejamento de futuro" (assistente da empresa B).

"Aqui eles nem olham na cara da faxineira. Sei que ela sofre com isso...Mas vai falar isso com a diretoria...Eles não estão nem ai...Não preocupam nem com os outros parentes deles que também são diretores vão se preocupar com o chão de fábrica???" (gestor da empresa A).

A realização profissional é um grande indicador de prazer no trabalho, mostrando-se de acordo com Mendes (2005), como um dos fatores que influenciam as vivências de prazer e o bem-estar no trabalho.

Segundo Mendes (2003), a realização se refere a um "sentimento de gratificação, orgulho e identificação com um trabalho que atende às necessidades profissionais" (p.6). O alcance da Realização Profissional com certeza envolve alguns indicadores, ou seja, existem fatores que levam a esta realização. Estes fatores podem ser valores individuais e organizacionais, supondo que haja uma relação entre os valores de indivíduo e sua Realização Profissional, assim como desta com os valores da organização em que atua. Realizar-se pessoal e profissionalmente é um dos valores individuais do ser humano.

\subsubsection{Dinâmica que envolve as vivências de prazer e sofrimento: "o dia do salário é o dia do prazer e o do sofrimento é levantar cedo todos os dias"}

O sentimento de prazer verificado na fala dos entrevistados esteve muito vinculado às oportunidades de realização dentro da empresa, identificação com um trabalho que atende às aspirações profissionais, o reconhecimento do seu trabalho e a capacidade de produzir e reproduzir algo. A vivência de prazer no trabalho resulta ainda no sentir-se útil, produtivo e valorizado, gerando sentimento de orgulho e admiração pelo trabalho realizado, tendo inclusive a aprovação da chefia e dos colegas. 
"Fico muito satisfeita com a minha função nessa empresa, vejo que consigo fazer a maioria das coisas que eu acho que são certas, mas claro colocando sempre prioridades e respeitando sempre o que a diretoria me solicita, mesmo não concordando com algumas coisas" (assistente da empresa A).

"Fico muito feliz quando me levanto e venho para o trabalho. Gosto muito do que realizo aqui. Cada dia é um dia. Tem dias difíceis, mas tem outros dias muito bons. Um dia compensa o outro" (gestor da empresa B).

"O dia do salário é o dia do prazer, mesmo ele sendo único, mas é um dia que te faz levantar todos os outros. Tem também as amizades que se criam ali, o conhecimento profissional mesmo, intelectual de cada um ali” (assistente da empresa B).

"Para mim prazer é o trabalho que te impulsiona, que te faz acordar e sentir bem porque tem um emprego bom” (assistente da empresa B)

"Sentimento de prazer é aquilo que te faz crescer, te faz ser grande e isso que te faz ser grande é o que te faz você trazer pessoas junto com você" (gestor da empresa A).

"Prazer é você se sentir realizado profissionalmente e que as pessoas que estão ao teu redor possam valorizar o seu trabalho, é você também se sentir realizado pessoalmente, financeiramente, enfim a relação de prazer no trabalho está muito ligado a nossa vida pessoal também, os dois devem estar em constante sintonia” (gestor da empresa C).

"Prazer é causado pela sensação de dever cumprido, pela produtividade, pela utilidade" (assistente da empresa C).

A descrença na empresa foi outro fator encontrado e que interferia nas vivências de sofrimento dos participantes. Isso se dá pelo fato de que a diretoria não dá apoio nem tenta resolver os conflitos que surgem no ambiente de trabalho. Ocorre também pela falta de diálogo sobre as dificuldades enfrentadas no dia-a-dia do trabalho e tudo isso se justifica porque as empresas só querem saber do retorno financeiro. 
"Eu nunca fui reclamar com a diretoria sobre o meu problema com a colega da equipe porque sabia que eles não iriam fazer nada. Um dia percebi que ela foi lá e reclamou com um dos diretores. Ai fui lá também e falei tudo..No final das contas ele mandou eu dar as soluções. Eu dei mas não adiantou.E ela continua lá até hoje porque não pode ser demitida.Meus dias eram de extremo desespero" (gestor da empresa A).

“As pessoas não conversam sobre suas dificuldades porque sabem que não serão escutadas. Eles só querem saber de ganhar dinheiro, do lucro mesmo. Isso faz a gente sofrer ainda mais, porque tem que ficar guardando essas coisas ruins" (assistente da empresa B).

Alguns entrevistados relataram sentimentos de sofrimento em relação ao trabalho que executam quando algo não sai conforme planejado ou quando existe uma decepção com o colega de trabalho por se esperar algo dele e não ser correspondido; e que as pessoas preocupam mais com o individual do que com o coletivo.

"Sofro quando uma coisa dá errada e não consigo solucionar ou não sei como fazer. Como a gente trabalha no comércio, às vezes a gente tem clientes que satisfaz com o nosso trabalho e outros não. Isso pra mim já é um sofrimento enorme. Um cliente vim e discutir com você ou expor uma coisa que você fez de errado" (gestor da empresa B).

"Sofrimento é você ver pessoas que você acreditava e que não dá valor naquilo que você está dando" (gestor da empresa A).

"O meu grande sofrimento foi perceber que não é todo mundo que consegue enxergar que o ganho não é individual e sim da equipe. Você não consegue as coisas sozinho. Não é todo mundo que tem a cabeça aberta ou uma cabeça grande para entender isso" (gestor da empresa A).

"Se as pessoas se aproximassem já seria anestésico mais eficiente do que as recompensas. Assim eles se sentiriam mais próximos, sentiriam vontade de pensar alguma coisa" (assistente da empresa B).

Ferreira e Mendes (2003) sustentam que o prazer no trabalho é vivenciado quando há satisfação dos desejos e das necessidades do trabalhador e quando há uma mediação bem 
sucedida dos conflitos gerados pelo contexto de trabalho. Assim, acredita-se que as vivências de prazer estão relacionadas a contextos de trabalho onde seja possível realizar atividades com início, meio e fim, onde o indivíduo possa perceber o produto de seu trabalho (FERREIRA; BARROS, 2003).

Já o sofrimento pode estar vinculado a subutilização do potencial técnico e criativo, à rigidez hierárquica, ingerência política, centralização de informações, falta de participação nas decisões, não-reconhecimento e pouca perspectiva de ascensão profissional (FERREIRA; MENDES, 2001).

Como fonte de sofrimento, o trabalho se manifesta sob experiências dolorosas, como angústia, medo e insegurança, transformando-se em algo penoso, principalmente quando a organização ignora os desejos e necessidades do trabalhador (DEJOURS, 1992; FERREIRA; MENDES, 2003). 


\section{Conclusão}

O presente estudo teve como objetivo investigar as vivências de prazer e sofrimento no trabalho de gestores de pessoas e seus assistentes em três empresas familiares na área de comércio. O número de participantes por empresa pode não ser representativo por se tratarem de empresas com um número pequeno de funcionários, mas esse estudo pode contribuir para aumentar o foco sobre os profissionais da área de Gestão de Pessoas, ressaltando que essa área não pode resumir-se a um conjunto de políticas e práticas, tampouco ser definida como responsabilidade de um departamento ou de uma função. Com essa pesquisa, notou-se que a área de Gestão de Pessoas não exerce a real função dentro das empresas e não podem dar suporte a situações de prazer e sofrimento no trabalho porque os próprios gestores de pessoas não são reconhecidos pelo trabalho que executam (estritamente de recursos humanos) e muito menos abordarem assuntos como esse. Seria interessante numa próxima pesquisa verificar vivências de prazer e sofrimento em empresas de grande porte e não familiares.

Nas empresas pesquisadas notou-se que os funcionários, mesmo aqueles que não se sentem em situações de sofrimento no trabalho, preocupam-se e se mostraram interessados no assunto. Caso as organizações continuem a serem vistas apenas com o olhar da objetividade, levando em conta tão somente as pressões do mercado e sem considerar o indivíduo, com certeza estarão perdendo resultados a longo prazo, pois, fenômenos como sofrimento no trabalho trazem conseqüências prejudiciais às organizações como demonstrado nos vários estudos citados no presente trabalho e inclusive nas organizações pesquisadas.

Foi possível comprovar a coexistência da díade prazer-sofrimento, conforme disseminado pela literatura (MENDES; MORRONE, 2002), mas notou-se que o trabalho nessas empresas estudadas evoca, predominantemente, vivências de sofrimento nos participantes, ou, na percepção deles, esse tipo de vivência denota maior impacto.

Os conteúdos das tarefas também apresentam, em sua grande maioria, diversos fatores que podem ser geradores de sofrimento e/ou adoecimento. As tarefas executadas apresentam conteúdos repetitivos e monótonos, desprovidos de sentido e significado. Pode-se dizer que para essas tarefas tornarem-se significativas deve haver uma tentativa de combinar produtividade e organização do trabalho, tendo como parâmetro a busca de uma correspondência entre as necessidades físicas e psicossociais dos trabalhadores aos conteúdos da tarefa, regras e autonomia no trabalho utilizado por eles.

Para tal, é necessário um sistema de inovação que integre produtos e processos na área técnica, organizacional, gerencial e em nível da diretoria, principalmente. A mudança de 
paradigma implica transformação da prática direcional. O novo paradigma permite trocas completas que vão além das trocas técnicas, e é responsável pela reestruturação de todo o sistema produtivo. Uma nova lógica deverá ser instalada para a atividade produtiva, dando origem a novos significados para os equipamentos e critérios eficientes para organização.

Esta eficiência está relacionada com a integração entre "como fazer" e os resultados, bem como com a descentralização das decisões, autonomia, flexibilidade hierárquica, criatividade, incentivo à participação, valorização e qualificação dos trabalhadores.

A participação dos trabalhadores nas decisões e transformações referentes à organização do trabalho é essencial para a promoção do prazer no trabalho. Não obstante, determinados processos de produção inibem a iniciativa e suprimem a criatividade, valorizando a rigidez e a eficiência individual.

Com relação às regras, nas empresas pesquisadas elas sempre são acompanhadas e existem muitas cobranças, para baterem as metas, cuidarem da aparência física e o bom atendimento ao cliente. Já os gestores de pessoas ficam limitados ao processo de recrutamento e seleção.

A autonomia não foi encontrada em nenhum relato por parte dos trabalhadores, pois eles dizem obrigados a seguirem as ordens da diretoria e as normas da empresa. Alguns gestores reclamaram que o processo de recrutamento e seleção muitas vezes são enviesados, sofrendo interferências por parte da diretoria, que colocam muitas vezes seus familiares.

As relações socioprofissionais apresentam, no geral, fatores que são indicativos de sofrimento, tais como controle diário das chefias que inibem os trabalhadores de opinarem ou até mesmo solicitarem mudanças. Alguns trabalhadores relataram ainda sobre o despreparo dos chefes para assumirem tais cargos, como por exemplo: dificuldade de comunicação, grosserias e falta de conhecimento intelectual. O relacionamento interpessoal na equipe foi visto como um ponto positivo por poucos trabalhadores que relataram sobre o bom relacionamento na equipe, onde alguns a consideram como uma família, outros prezam pela comunicação, em saber lidar com as diferenças e não levar problemas pessoais para o trabalho, separando assim o pessoal do profissional. Já outros trabalhadores os vêem como negativo pelo fato de que a convivência na equipe é difícil, as pessoas não aceitam receber informações, não se preocupam com o outro, não se tratam com igualdade, não querem compartilhar informações e relatam ainda que exista muita fofoca nas equipes.

Quanto ao reconhecimento, os auxiliares relataram que ele se dá através de premiações, bônus sempre que cumprem as metas e que a diretoria não se interessa como elas foram cumpridas, mas sim com os resultados. Existem reclamações sobre a competitividade 
no ambiente de trabalho, o que gera sentimento de injustiça para aquele que trabalhou de acordo com as regras e muitas vezes quem ganha é aquele que transgrediu as regras e não respeitou os colegas.

Não foi verificado na falas dos gestores um reconhecimento que visasse qualidade do seu trabalho, dos esforços, das angústias, das dúvidas, decepções e desânimos que emergem no dia-a-dia do trabalho. Eles sentem que todo esse sofrimento é como se tivesse sido em vão, acreditando que não trouxeram nenhuma contribuição à organização do trabalho.

Entretanto, na tentativa de evitar situações de sofrimento e prevenir a saúde, os trabalhadores faziam uso principalmente de estratégias de defesa (negação e racionalização). Relacionado a isso, Dejours (2000) acrescenta que para controlar o sofrimento, os trabalhadores usam estratégias de defesa que são especificamente marcadas pelas pressões reais no trabalho. A análise do funcionamento dessas estratégias mostra que elas podem contribuir para tornar aceitável aquilo que não deveria sê-lo.

O autor ainda sustenta que sofrimento no trabalho, sobretudo o sofrimento psíquico, é uma questão negligenciada pelas organizações. O primeiro acontecimento que justifica essa constatação é a recusa sindical em considerar a subjetividade. O segundo é a vergonha de tornar público o sofrimento gerado pelos novos métodos de gestão de pessoas.

No entanto, Mendes e Morrone (2002) explicam que as vivências de prazer e de sofrimento coexistem na relação do trabalhador com seu trabalho e que o indicador de saúde no trabalho não é a simples existência de sofrimento ou prazer, mas a diversidade de estratégias utilizadas pelos trabalhadores na tentativa de transformar situações geradoras de sofrimento em situações geradoras de prazer.

Quanto à realização profissional, que é um grande indicador de prazer no trabalho, pode ser verificada na fala de dois trabalhadores quando relataram que o cargo que assumem é fruto de satisfação e inclusive realização de um sonho. Outros entrevistados relataram que não estão realizados profissionalmente, inclusive que alguns assistentes sentem-se insatisfeitos pela falta de perspectiva de crescimento dentro da empresa. Já os gestores de pessoas falaram sobre a falta de credibilidade que a área de Gestão de Pessoas tem na organização e falta de reconhecimento do seu trabalho também. Relataram ainda dificuldade de implantar projetos e lidar com a diretoria que visa o trabalhador somente como custo e recurso.

A dinâmica que envolve o prazer e o sofrimento no trabalho foi notado constantemente na fala dos trabalhadores. O prazer esteve vinculado ao salário e à realização profissional em dois casos. Mas a predominância foi a de sofrimento causado principalmente pela descrença na empresa pela relação com a incompatibilidade entre organização do 
trabalho e o investimento psicológico dos trabalhadores e inclusive, pela ausência de suporte organizacional. O sofrimento não se manifestou claramente e sim por meio da ansiedade, insatisfação, desqualificação, desvalorização e outros fatores mais.

A dominação e o controle que as organizações exercem sobre os trabalhadores, seja de forma explícita, seja por meio do "não dito" do discurso organizacional (FREITAS, 2000), os influencia de alguma forma, independente da natureza de seu trabalho e provoca alterações nas relações sociais que estabelecem dentro e fora da organização (MENDES; MORRONE, 2002). Dejours (2000) considera que, ao mesmo tempo em que as organizações reproduzem o sofrimento e a injustiça, prometem felicidade e realização para aqueles que se adaptam a ela e contribuem para o seu sucesso e excelência. Assim, as organizações passam a ser caracterizadas pela sua gestão, ao invés de sua produção ou trabalho como antes e desqualifica as preocupações com o trabalho, tanto no nível econômico, quanto social e psicológico.

Um aspecto interessante para consideração de administradores e gestores de pessoas das organizações emerge da análise das dificuldades que se colocam habitualmente, aos níveis administrativos mais distanciados dos operadores, para uma percepção do sofrimento mental destes trabalhadores. Assim, direção e gerência de escalão superior encontram dificuldades para identificar as causas de determinadas falhas, ou mesmo fracassos da produção, que são decorrentes do sofrimento mental engendrado pela situação de trabalho e, geralmente de modo mais específico, pela organização prescrita para o trabalho.

Para uma política contínua e de real prevenção, faz-se necessário um investimento em comunicação e treinamento dos funcionários, tanto gestores quanto os auxiliares que ocupam os menores cargos. É preciso que as pessoas comecem a discutir abertamente e de forma clara o assunto de prazer e sofrimento no trabalho. Se a empresa não ocupar esse espaço de esclarecimento, os casos vão se multiplicar e nem sempre estarão relacionados efetivamente ao sofrimento no trabalho.

Espera-se, do ponto de vista acadêmico, que a presente pesquisa abra campo para outros estudos nos quais se procure desenvolver o conhecimento teórico sobre a área de Gestão de Pessoas, especialmente estudos voltados para a busca de indicadores de prazer e sofrimento no trabalho. Do ponto de vista das organizações, espera-se que os resultados da pesquisa ofereçam contribuições àqueles que atuam nas áreas de Gestão de Pessoas, à medida que são apontadas, em cada dimensão do estudo, as ações que precisam ser melhores trabalhadas. 


\section{REFERÊNCIAS}

ALBUQUERQUE, L. G. O papel estratégico de recursos humanos. Tese (Livre Docência) - Faculdade de Economia, Administração e Contabilidade, Universidade de São Paulo. São Paulo, 1987.

ALBUQUERQUE, L. G. Competitividade e recursos humanos. Revista de Administração, v. 27, n. 4, out./dez. 1992.

ABRAHÃO, J. I.; ALMEIDA, A. Diversidade: gestão e capacitação da força de trabalho. Relatório apresentado à Organização Internacional do Trabalho - OIT. 1998.

ANTUNES, R. Adeus ao trabalho? São Paulo: Cortez, 1995.

ANTUNES, R. Os sentidos do trabalho. São Paulo: Boitempo, 1999.

BARROS, P. C. R. \& MENDES, A. M. B. Sofrimento psíquico no trabalho e estratégias defensivas dos operários terceirizados da construção civil. Net, São Paulo, jun. 2003. Disponível em $<\quad$ http://scielo.bvs-psi.org.br/scielo.php?pid=S141382712003000100009\&script=sci_arttext $>$. Acesso em: 30 out. 2007.

CHIAVENATO, I. Gestão de pessoas: o novo papel dos recursos humanos nas organizações. Rio de Janeiro: Campus, 1999.

DAVEL, E; VERGARA, S. C. Gestão com Pessoas e Subjetividade. São Paulo: Editora Atlas, 2001.

DEJOURS, C. A loucura do trabalho: estudo de psicopatologia do trabalho. São Paulo: Cortez, 1992.

DEJOURS, C. Uma nova visão do sofrimento humano nas organizações. In: CHANLAT, Jean-François (Coord.). $O$ indivíduo na organização: dimensões esquecidas. $3^{\mathrm{a}}$ ed. São Paulo: Atlas, 1996.

DEJOURS, C. A banalização da injustiça social. Rio de Janeiro: FGV, 2000.

DEJOURS, C. A metodologia em psicopatologia do trabalho. In: LANCMAN, S.; SZNELWAR, L. I. Christophe Dejours: Da psicopatologia à psicodinâmica do trabalho. Rio de Janeiro: Fiocruz, 2004, cap 2.

DEJOURS, C. O fator humano. Rio de Janeiro: FGV, 2005.

DEJOURS, C., ABDOUCHELI, E. \& JAYET, C. Psicodinâmica do trabalho: contribuições da escola dejouriana à análise da relação prazer, sofrimento e trabalho. São Paulo: Atlas, 1994.

ENRIQUEZ, E. A organização em análise. Petrópolis: Vozes, 1997. 
FERREIRA, M. C. Atividade, categoria central na conceituação de trabalho em ergonomia. Revista Alethéia, Canoas - RS, v. 1, n. 11, p. 71-82, 2000.

FERREIRA, M.C., BARROS, P.C. (In) Compatibilidade trabalho prescrito - trabalho real e vivências de prazer-sofrimeto dos trabalhadores: um diálogo entre a ergonomia da atividade e a psicodinâmica do trabalho. Alethéia,.Canoas, v. 1, n. jul/dez, p. 115-128, 2003.

FERREIRA, M. C.; MENDES, A. M. B. "Só de pensar em vir trabalhar, já fico de mau humor": atividade de atendimento ao público e prazer-sofrimento no trabalho. Revista Estudos de Psicologia, Natal, v.6, $n^{\circ}$ 1, p. 97-108, 2001.

FERREIRA, M. C.; MENDES, A. M. B. Trabalho e riscos de adoecimento: o caso dos auditores fiscais da Previdência Social brasileira. Brasília: Ler, Pensar, Agir, 2003.

FISCHER, A. L. As Pessoas na Organização. São Paulo: Gente, 2002.

FREITAS, M. E. Cultura Organizacional: identidade, sedução e carisma? Rio de Janeiro: FGV, 2000.

JABBOUR, C. J. C.; SANTOS, F. C. A. Desenvolvimento de produtos sustentáveis: o papel da gestão de pessoas. Rev. Adm. Pública, Rio de Janeiro, v. 41, n. 2, 2007 . Disponível em: $\quad<$ http://www.scielo.br/scielo.php?script=sci_arttext\&pid=S0034$76122007000200007 \& \operatorname{lng}=$ pt\&nrm=iso $>$. Acesso em: 19 Out 2007.

LACOMBE, B. M .B.; TONELLI, M. J. O Discurso e a Prática: o que nos Dizem os Especialistas e o que nos Mostram as Práticas das Empresas sobre os Modelos de Gestão de Recursos Humanos. RAC, v. 5, n. 2, Maio/Ago. 2001.

LIMA, M. E. A. Novas políticas de recursos humanos: seus impactos na subjetividade e nas relações de trabalho. Revista de Administração de Empresas, v. 34, nr. 3, p. 115-124, 1994.

MACHADO, M. Equipes de trabalho: sua efetividade e seus preditores. Tese (Mestrado) Universidade de Brasília. Brasília, 1998.

MARTiningO, A. F. Assédio Moral e Gestão de Pessoas: Uma análise ao assédio moral no trabalho e o papel da área de Gestão de Pessoas. Tese (Livre Docência) - Universidade de Brasília. Brasília, 2007.

MENDES, A. M. Comportamento defensivo: uma estratégia para suportar o sofrimento no trabalho. Revista de Psicologia, 13/14 (1/2), 27-32, 1996.

MENDES, A. M. Cultura organizacional e prazer-sofrimento no trabalho: uma abordagem psicodinâmica. In: TAMAYO, A. et al. Cultura e saúde nas organizações. Porto Alegre: Artmed, 2004.

MENDES, A. M.; FERREIRA, M. C.; FACAS, E. P.; VIEIRA, A. P. Validação do Inventário de Trabalho e Riscos de Adoecimento - ITRA. In: IV CONGRESSO NORTE NORDESTE DE PSICOLOGIA, 2005, Salvador. Anais do IV Congresso Norte Nordeste de Psicologia. Salvador: UFBA, 2005. 
MENDES, A. M. Pesquisa em psicodinâmica: a clínica do trabalho. In: MENDES, A. M. (org.) Psicodinâmica do trabalho: teoria, métodos, pesquisas. 1 ed. São Paulo: Casa do Psicólogo, 2007.

MENDES, A. M.; MORRONE, C. F. Vivências de Prazer-Sofrimento e Saúde Psíquica no Trabalho: trajetória conceitual e empírica. In MENDES, A. M. (Org.). Trabalho em transição, saúde em risco. Brasília: Editora Universidade de Brasília, 2002.

NOBREGA, M. F.; FERRUCCIO, M. A. Gestão Estratégica de Pessoas - Melhores Práticas de Recrutamento, Seleção e Treinamento. Net, Rio de Janeiro, nov. 2002. Disponível em $<$ http://www.latec.uff.br/anais/Artigos/107.pdf>. Acesso em: 19 Out 2007.

PAGÈS, M. et al. O poder das organizações. São Paulo: Atlas, 1987.

PIMENTA, S. M. Recursos humanos: uma dimensão estratégica. Belo Horizonte: UFMG, 1999.

RUAS, R. Aprendizagem nas Organizações e Desenvolvimento de Competências. Porto Alegre: PPGA/UFRGS. Mimeo, 2004.

SACOMANO N., Mário; ESCRIVAO F., Edmundo. Estrutura organizacional e equipes de trabalho: estudo da mudança organizacional em quatro grandes empresas industriais. RAE-

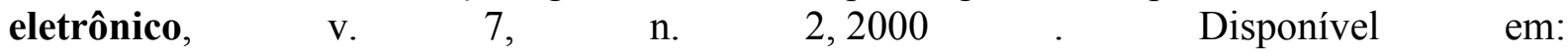
$<$ http://www.scielo.br/scielo.php?script=sci_arttext\&pid=S0104-

530X2000000200004\&lng=pt\&nrm=iso $>$. Acesso em: 09 Abr 2008. doi: 10.1590/S0104$530 \times 2000000200004$

SCHULER, R.; JACKSON, S. Gestão de Recursos Humanos: tomando posição para o século XXI. Revista Comportamento Organizacional e Gestão, v. 3 n. 2, p. 255-274, 1997.

SIQUEIRA, M. V. S. Gestão de Pessoas e Discurso Organizacional. Goiânia: UCG, 2006.

VASCONCELOS, I.; MASCARENHAS, A. O.; VASCONCELOS, F. C. Paradoxos Organizacionais, Gestão de Pessoas e Tecnologia na Souza Cruz. RAE-eletrônica, v. 3, n. 2, Art. 25, jul./dez. 2004. Disponível em: $<$ http://www.scielo.br/scielo.php?script=sci_arttext\&pid=S167656482004000200010\&lng=en\&nrm=iso>. Acesso em: 24 Oct 2007.

ZANELLI, J. C.; BORGES-ANDRADE, J. E.; BASTOS, A. V. B. Psicologia, Organizações e Trabalho no Brasil. Porto Alegre: Artmed, 2004. 
ANEXOS

ANEXO A - Roteiro de Entrevista.

ANEXO B - Perfil dos Entrevistados. 


\section{ANEXO A - ROTEIRO DE ENTREVISTA}

PARTE I:

\begin{tabular}{|l|l|}
\hline ENTREVISTA NR. & \\
\hline IDADE & \\
\hline SEXO & \\
\hline FORMAÇÃO & \\
\hline CARGO & \\
\hline ÁREA & \\
\hline TEMPO DE TRABALHO & \\
\hline DATA DA ENTREVISTA & \\
\hline
\end{tabular}

\section{PARTE II:}

\section{Prazer e Sofrimento no trabalho:}

1) Fale-me o que lhe vem à mente quando ouve a palavra trabalho;

2) Fale-me sobre seu trabalho e sobre seus sentimentos em relação ao seu trabalho desde quando se encaminha ele;

3) Como você se sente ao final de um dia de trabalho e como faz para dar conta/lidar/enfrentar o seu dia-a-dia de trabalho?

4) O que você entende por prazer e sofrimento no trabalho?

5) O que pode causar o prazer no trabalho? E o que pode causar o sofrimento?

6) Como é possível diminuir esses sofrimentos?E como é possível potencializar o prazer no trabalho?

\section{A área de Gestão de Pessoas e o Prazer e Sofrimento no Trabalho:}

7) Como você vê a área de Gestão de Pessoas dentro da sua organização?

8) Qual é o papel da área de Gestão de Pessoas frente ao fenômeno prazer e sofrimento no trabalho? 
9) O clima organizacional no ambiente de trabalho pode influenciar no surgimento de casos de sofrimento no Trabalho?De que forma a área de Gestão de Pessoas poderia diminuir esses riscos?

10) Os sistemas de recompensa (bônus) adotados pelas organizações podem influenciar no surgimento de casos de Sofrimento no Trabalho? De que forma a área de Gestão de Pessoas poderia diminuir esses riscos?

11) Os treinamentos que você já realizou durante a sua carreira, abordaram aspectos relacionados ao Prazer e Sofrimento no Trabalho?

12) Você acha que a discussão desse assunto (Prazer e Sofrimento no Trabalho) é importante nas organizações? De que forma a área de Gestão de Pessoas pode propiciar essa discussão? 


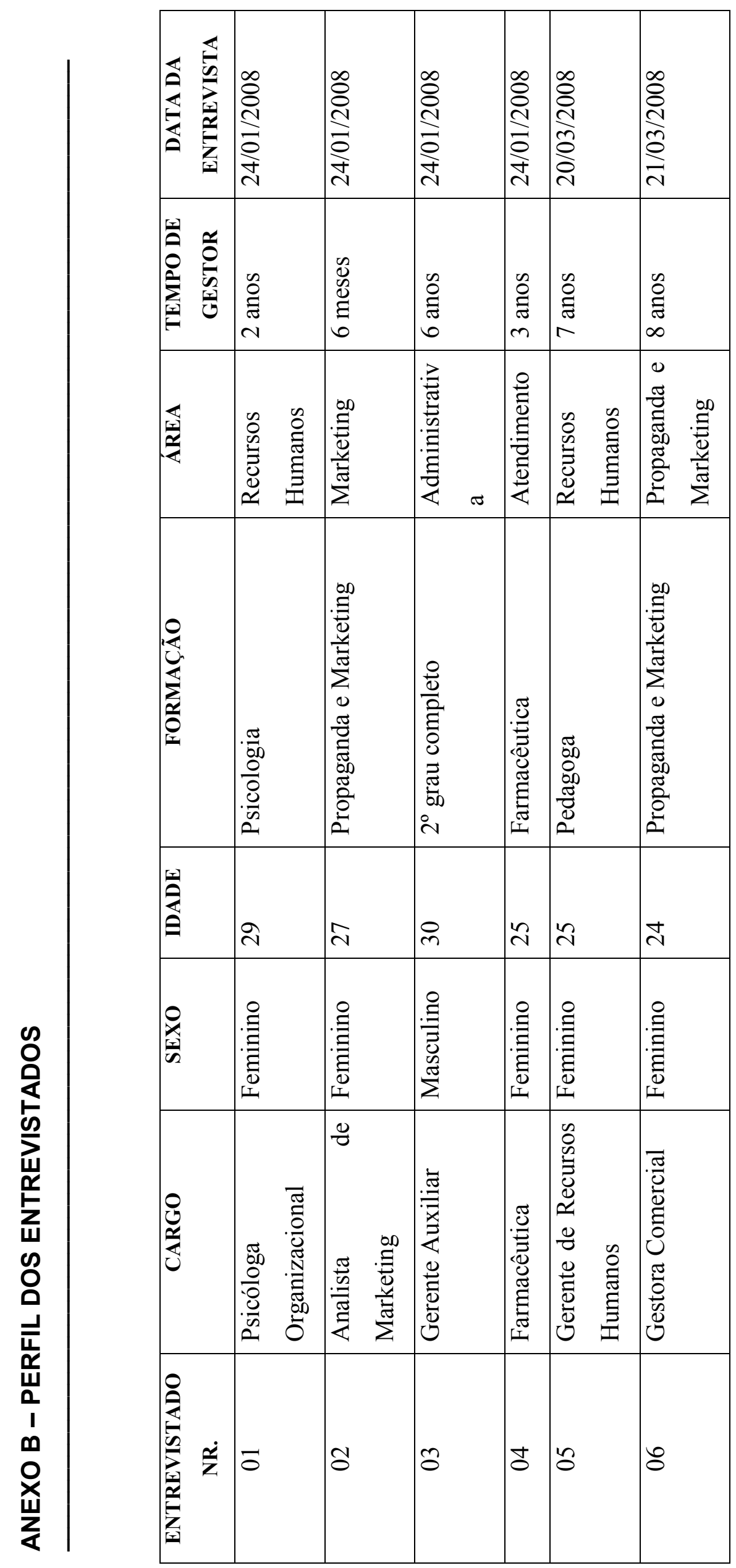

